Portland State University

PDXScholar

Summer 8-6-2014

\title{
An Analysis of Vegetation Recovery following Dam Removal at Hemlock Recreation Site, Washington
}

Greer Stewart Ramsey
Portland State University

Follow this and additional works at: https://pdxscholar.library.pdx.edu/open_access_etds

Part of the Environmental Monitoring Commons

Let us know how access to this document benefits you.

\section{Recommended Citation}

Ramsey, Greer Stewart, "An Analysis of Vegetation Recovery following Dam Removal at Hemlock Recreation Site, Washington" (2014). Dissertations and Theses. Paper 2003.

https://doi.org/10.15760/etd.2002

This Thesis is brought to you for free and open access. It has been accepted for inclusion in Dissertations and Theses by an authorized administrator of PDXScholar. Please contact us if we can make this document more accessible: pdxscholar@pdx.edu. 
An Analysis of Vegetation Recovery following Dam Removal at Hemlock Recreation Site, Washington

by

Greer Stewart Ramsey

A thesis submitted in partial fulfillment of the requirements for the degree of

Master of Science

in

Geography

Thesis Committee:

Martin Lafrenz, Chair

Martha Works

Sarah Eppley

Portland State University

2014 


\begin{abstract}
Dam removals are becoming increasingly common as dams reach their life expectancy and face costly upgrades associated with relicensing. Though removal is often viewed as a success in terms of ecological restoration, it also represents a major disturbance to an area. Previous research has shown that native species do not survive as well at these disturbed sites, and invasive species often dominate. This study examines the vegetation response in the drained reservoir area after the removal of Hemlock Dam on Trout Creek, a tributary to the Wind River in southern Washington. Transects were established and quadrats were sampled to determine the plant classifications and cover of vegetation and to examine possible correlations between environmental variables and the spatial distribution of plant classification groups. Sampling took place in the third and fourth years following dam removal, and the data was analyzed to determine significant changes and relationships.
\end{abstract}

The results of this study showed that the site was dominated by a volunteer native forb Lotus purshianus (Spanish clover) and a planted native tree Alnus rubra (red alder). Most of the other species found were native volunteer forbs and grasses characteristic of early succession in this region. Both invasive species and planted species, with the exception of Alnus rubra, had low canopy covers. There was a significant increase in native plant canopy cover, as well as total canopy cover, from 2012 to 2013 . There were also significant relationships between plant classification groups and environmental variables, including soil infiltration, elevation, and distance from stream. This study will help inform resource managers about the kinds of plants that will volunteer after dam removals and the possible success of re-vegetation projects. 


\section{ACKNOWLEDGEMENTS}

I would like to thank Dr. Martin Lafrenz for introducing me to the Hemlock Dam removal site, teaching me about soils, geomorphology, and dam removals, advising me on the best approaches to fieldwork, and guiding me through the process of writing a thesis. Thank you to Dr. Martha Works for offering the insight of a human geographer. Also, thank you Dr. Sarah Eppley for helping me with study design and data analysis from the perspective of a biologist. My gratitude extends to Sarah Woodcock, Annie Scriven, and Melisa Mahoney for their enthusiastic help with fieldwork. I would also like to thank Professor Emeritus Larry Price, and his wife Nancy, for funding this research through their generous Price Scholarship. 


\section{TABLE OF CONTENTS}

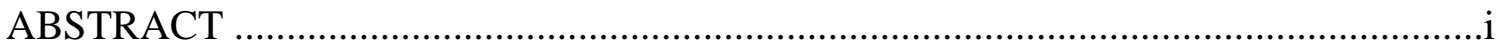

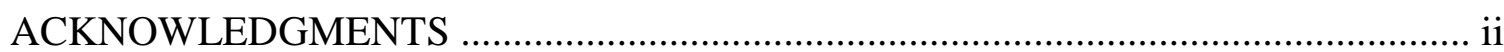

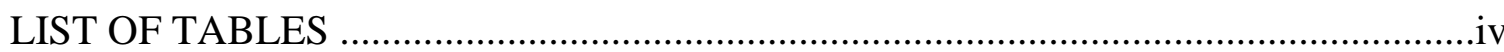

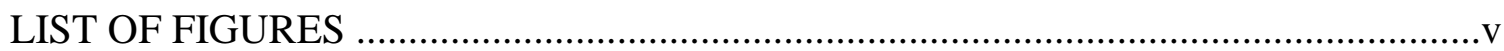

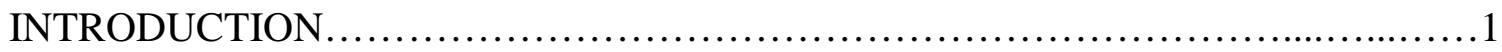

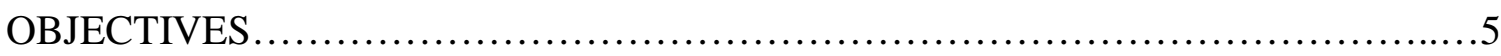

PREVIOUS WORK.........................................................

Vegetation and Dam Removal............................................... 7

Primary Succession in the Pacific Northwest.................................11

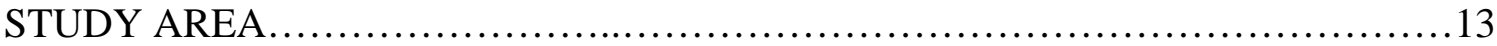

Site Overview...................................................... 15

Re-vegetation after Dam Removal.................................... 17

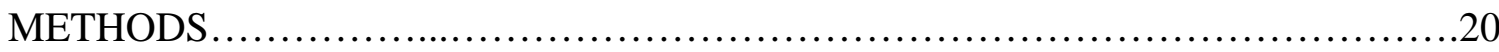

Field Sampling Methods................................................20

Data Analysis........................................................ 24

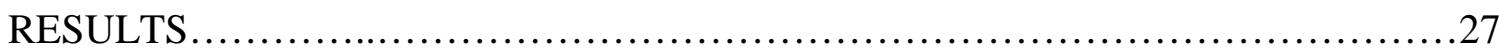

Differences between Years.............................................29

Correlations with Environmental Variables.................................42

DISCUSSION .............................................................. 45

Vegetation Recovery after Dam Removal................................45

Success of Planting...................................................52

Influence of Environmental Variables on Vegetation..........................55

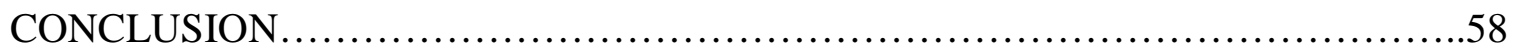

REFERENCES...........................................................61 


\section{LIST OF TABLES}

Table 1. Species planted by USFS staff and volunteers in 2009 through 2011 (Ruchty 2011)

Table 2. Daubenmire cover classes used in this study..... .22

Table 3. Species and their abundance, ranked by canopy cover, in the 22 quadrats sampled

Table 4. Species and their abundance, ranked by canopy cover, in the 45 quadrats sampled in 2013 .32

Table 5. Outcome of Wilcoxon Signed Ranks Test performed on Daubenmire results....34

Table 6 . Results of paired t-tests by plant classifications.......................... 36

Table 7. Species richness and Simpson's Index across the site......................37

Table 8. Distribution of growth habit of species found on site.........................38

Table 9. Distribution of native status of species found at the site....................41

Table 10. Results of paired t-tests on 44 quadrats sampled in $2013 \ldots \ldots \ldots \ldots \ldots \ldots \ldots . . . .41$

Table 11. Distribution of volunteer and planted species at the site...................42

Table 12. Environmental variables measured at each quadrat.........................43

Table 13. Correlations of classification groups with environmental variables............44 


\section{LIST OF FIGURES}

Figure 1. Hemlock Dam from below dam (left) and the reservoir as seen from bridge (right) (Randle and Greimann 2004)....................................13

Figure 2. Former reservoir area immediately after dam removal, from bridge (Coffin 2011) and from a Google Earth image dated 10 September 2009 (right)..........15

Figure 3. Watershed context of Hemlock Recreation Site............................ 16

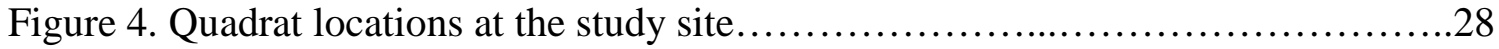

Figure 5. Examples of quadrats sampled at the site.............................29

Figure 6. Rank abundance curve fit with a lognormal trendline........................

Figure 7. Lotus purshianus (left) and Alnus rubra (right) from the study site............48

Figure 8. Native forest vegetation just downstream of the dam removal...............49

Figure 9. Quadrat shaded by Alnus rubra (left), and quadrat with ample sun............50

Figure 10. Stunted Pseudotsuga menziesii found on the site........................55 


\section{INTRODUCTION}

Dam removal is a relatively recent phenomenon in the United States. In the early and mid-twentieth century, water resources managers focused on river reclamation through dam building for hydroelectric power, flood control, water supply, irrigation, and recreation (Born et al. 1998). As of 2006, one fourth of all dams in the United States had reached their life expectancy of 50 years (Orr and Stanley 2006). Negative impacts have been noticed from older dams as "water evaporated from reservoir surfaces or got choked by algal blooms; concrete crumbled under pressure and time; structures severed salmon migration, collected silt, and cost millions to repair or replace" (Babbitt 2002, 656). These concerns for public safety and the mounting economic costs prompted the first wave of dam removals in the 1990s. As evidence of the negative impacts of dams to river ecosystems accumulated, ecosystem restoration became another driving force for dam removal. Dams reduce ecological connectivity, decrease the movement of sediment and organic matter downstream, and change both upstream and downstream stream channel morphology (Born et al. 1998). They disturb or destroy riparian areas by inundating habitats upstream while reducing natural flood regimes downstream. This narrows the riparian zones along the reservoir, increases salinization downstream, and provides an opportunity for invasive species to colonize the disturbed habitats (Orr and Stanley 2006, Naiman and Décamps 1997, Nilsson and Beggren 2000).

In recent years, there have been several large dam removals in the Pacific Northwest. Faced with the costly fish passage upgrades associated with Federal Energy Regulatory Commission (FERC) relicensing, Portland General Electric made the decision to remove the Marmot hydropower dam on the Sandy River in 2007 (Major et al. 2012). 
Condit Dam on the White Salmon River in Washington was removed in 2012 due to similar costly fish passage upgrades mandated by FERC (PacifiCorp 2011) as were two dams on the Elwha River; Elwha dam was removed in 2011 and Glines Canyon dam is currently being removed (National Park Service 2013). In 2007 Hemlock Dam on Trout Creek, a tributary of the Wind River in southern Washington, was removed by the United States Forest Service (USFS); this hydroelectric and water supply dam was causing fish passage and water quality problems, and dam removal was originally recommended in a report commissioned by the USFS and supported by the Bonneville Power Administration (Coffin 2011).

The Hemlock Dam removal led to the research for this study, in which I assess the response of vegetation communities to this dam removal and document the effect of active restoration by managed re-vegetation of native plants following this unique disturbance event. This is the first post-dam removal vegetation study done at this site and the only one done, other than Rohdy (2013), outside Wisconsin. The large area of the former reservoir and its topographic variability make it an ideal location to study succession processes following dam removal; by studying natural vegetation response over two years as well as documenting the effectiveness of active restoration, this study will explore the probable effects of future dam removals on Pacific Northwest riparian habitats.

Although dam removal itself, as well as the dewatering of the former impoundment, is a significant disturbance to the ecosystem, when carefully planned and managed this action may be able to mitigate some of the effects of dam building. It provides an opportunity for restoring flows, which may allow for re-colonization of 
native aquatic and riparian populations both upstream and downstream of the former dam in these restored ecosystems. The drained reservoir upstream, as well as the sediment deposited downstream, may create a setting for native plant communities to reestablish themselves. However, dam removal also has the potential to leave bare reservoir sediment that is very different both chemically and physically from pre-dam floodplain sediments, with a fine texture, often low nutrients, and immature microbial communities (Shafroth et al. 2002, Michel, Helfield, and Hooper 2011). Or, in some cases, the nutrient levels may actually be much higher than pre-dam conditions because of the anoxic conditions in the sediment of the inundated reservoir (Lafrenz, Bean, and Uthman 2013). Reservoir sediments usually lack a native seed bank, so seeds come mainly from dispersion by water, wind, or re-vegetation by project managers (Michel, Helfield, and Hooper 2011). These sediments may be susceptible to invasion given that "high levels of physical disturbance result in significant proportions of exotic species in many riparian floras" (Shafroth et al. 2002, 709). This can prevent native species from establishing or at least reduce the diversity of native plant species, thus negatively impacting stream conditions and habitats (Naiman and Décamps 1997).

In the Pacific Northwest, most plant communities follow a similar trajectory of succession after a natural disturbance such as fire or flood. In the growing season following disturbance, some plants that were on site prior to the disturbance, as well as herbaceous species in the local seed bank, will colonize the site. The herbaceous species increase significantly in richness and dominate the landscape in the second year, which is often called the successional or weed stage. In the fourth or fifth year, both residual and shrub species take over, and eventually tree saplings begin to establish themselves. In 
moist riparian areas, Alnus rubra (red alder) is the most common tree to establish after disturbance. Rubus spectabilis (salmonberry) occupies the shrub layer, while Polystichum munitum (western sword fern) dominates in the herbaceous layer (Franklin and Dyrness 1973). Succession of plant communities following dam removal has received little research attention and, of course, may vary across regions. Dam removal dewaters an area that has been continuously inundated for decades and likely lacks a native seed bank. It is not a natural disturbance process and will likely resemble a primary rather than secondary succession. Therefore, it may be difficult to predict the responses of the vegetation community given the existing models of succession in the Pacific Northwest. 


\section{OBJECTIVES}

This study had two main objectives. The first objective was to assess vegetation changes from the third to fourth years following dam removal. The second objective was to determine whether environmental variables were influencing vegetation communities across the site. This research will help answer the following questions: After dam removal, do riparian communities follow a trajectory of succession similar to other disturbance events in the same region? Are vegetation communities that establish upstream of dam removals composed of mostly native or invasive species? Are revegetation efforts successful in establishing a diverse native plant community that resembles surrounding vegetation? Finally, is vegetation establishment related to environmental variables? I focus on the "new' riparian zone near the shore of the newly built stream channel, and examine species diversity and frequency of native and nonnative vegetation through two years of extensive vegetation surveys. The data are then analyzed to examine differences between years and to assess correlations between vegetation patterns and environmental variables in the second year.

Like dam building, dam removal is a human intervention that will inevitably affect natural systems. This is a recent phenomenon and few researchers have examined its implications. However, removals of small dams "will occur at a brisk pace for the foreseeable future" (Poff and Hart 2002, 667). One goal of many dam removal projects is to restore the natural flow regime and native ecosystems. Riparian vegetation "interacts strongly" with these other elements and can benefit restoration efforts by stabilizing sediments and increasing wildlife use (Shafroth et al. 2002, 703). 
A healthy riparian habitat is vital to the condition of the stream and watershed. Riparian zones are defined as "biotic communities on the shores of streams and lakes" (Naiman and Décamps 1997, 622). Researchers have found that these zones are an important source for plant and animal biodiversity in a watershed. They can also improve water quality by protecting streams from agricultural impacts, lowering water temperatures through shading, providing woody debris for fish habitat, and filtering pollutants. However, very little research has been done concerning the establishment of riparian vegetation communities following dam removal. The lack of research in this area could lead to uncertainties for water resource managers who want to ensure that removal sites establish a functioning native riparian community.

In addition to adding to the growing research about dam removals, this project reveals how specific vegetation colonizes and establishes itself on an area of bare sediment, thus adding to the body of knowledge on spatial and temporal dynamics of vegetation succession in highly disturbed areas. It will also contribute to information about the spread of invasive species to recently disturbed areas. The research will help reveal how planted species perform at dam removal sites, and it will inform project managers on possible results of re-vegetation projects. Finally, the results of this project will reveal further research questions that need to be investigated regarding vegetation establishment following dam removal. 


\section{PREVIOUS WORK}

\section{Vegetation and Dam Removal}

Researchers across the United States have evaluated general ecological responses to dam removal. Doyle et al. (2005) examined dams in Wisconsin and warned that ecosystems will probably never return to pre-dam conditions because of environmental damage or changes in the watershed that have taken place since dam installation. Doyle also collaborated with Stanley (2003) to review literature and argue that dam removal should be treated as a disturbance and "not as equal and opposite reactions to the effects of dams on rivers" (20). When deciding whether to remove dams, managers should consider the benefits and costs, and be aware that flora and fauna could be destroyed and ecosystem processes altered (Stanley and Doyle 2003). Bednarek (2001) looked at some of the short- and long-term effects of removal on ecology through literature studies. Short-term impacts include contaminated sediment release and supersaturation of gas, both of which may lead to fish mortality or destruction of spawning beds. Long-term effects are restoring natural flows and temperatures to the stream, and probable reestablishment of riparian and aquatic habitats (Bednarek 2001).

However, little field research has been done on the specific vegetation responses to dam removal. A few researchers have explored potential influences and responses and the role of invasive species. For instance, Shafroth et al (2002) provided a comprehensive review of case studies in the literature; they determined that downstream of a dam, newly deposited sediment can provide a setting for new vegetation but it could also bury existing vegetation. Upstream of the removed dam, vegetation that was inundated by a reservoir may now be only occasionally inundated, and vegetation that was on the edge 
of the reservoir may die because of lack of groundwater (Shafroth et al. 2002). Michel, Helfield and Hooper (2011) conducted pilot studies in greenhouses to determine how vegetation would respond to the removal of dams on the Elwha River. They collected seeds from nearby sites and found a very low density of wind-blown seed rain in the summer months, which is when the exposed sediments would be receptive to colonization by seeds. Just 2 of the 50 seeds collected had successful germination in the greenhouse; these were the native grass Deschampsia elongata (slender hairgrass) and the invasive grass Phalaris arundinacea (reed canarygrass). They also attempted to grow 3 plants that were being considered for re-vegetation and two invasive plants and found that all native plants did not survive as well on the reservoir sediments as they did on the alluvial sands that are currently in the riparian zone near the dams. This was also true for one of the invasive plants, however invasive Cirsium arvense (Canada thistle) did equally well on both substrates (Michel, Helfield, and Hooper 2011).

Some researchers have studied dam removal or reservoir drawdown in order to document the recovery of vegetation. In California's Lassen Volcanic National Park, Rohdy (2013) explored soils and vegetation one year after the removal of a small dam. She found that a mix of graminoids and forbs was establishing rapidly on the sediments and that most of the species were native. Interestingly, the species richness was higher at the study site than at reference sites nearby. Auble (2007) examined vegetation for four years after the drawdown of a reservoir in Colorado. He found that conditions on the exposed sediment changed from very wet to very dry over time, and yet the vegetation communities did not approach patterns that were found in the upland plant community. Lenhart (2000) looked at vegetation and hydrology at dam removals in southern 
Wisconsin and found that sediment depth and type, hydrology, and characteristics of certain plant species were the biggest influences in determining vegetation community structure. He also found that the timing of dam removal influenced vegetation communities because the species that established quickly, and persisted for years after, were those that went to seed at the time of removal (Lenhart 2000).

Most of the literature suggests that dam removal sites tend to attract invasive species. Shafroth et al. (2002) noted that early colonizing species, which are sometimes invasive, have been shown to grow quickly on the bare sediments in humid areas. Orr and Stanley (2006) examined vegetation development at thirty dam removals in southern Wisconsin. They found that although there was vegetation covering all removal sites, the average frequency of invasive species, especially reed canary grass, was 75 percent over the sites. Lenhart (2000) reported that some sites were occupied by a monoculture of invasive species, such as Urtica dioica (stinging nettle), which significantly reduced biodiversity. Woodward et al. (2011) performed extensive surveys around their project site to determine the extent that the seven invasive species found near the Elwha reservoir would colonize sediments after dam removal. They predicted that water would be the foremost transport for invasive seed after dam removal, and that areas near slack water would have the most invasive species because the slow water movement would allow more seeds to deposit there.

Studies regarding management of vegetation have revealed interesting trends. One of the goals of the study by Orr and Stanley (2006) was to determine how former reservoir sites are managed, and they discovered that only two of the thirty sites were revegetated following dam removal. Shafroth et al. (2002) argued that managed re- 
vegetation may prevent the colonization of invasive species and increase habitat diversity. Cook et al. (2011) investigated the use of arbuscular mycorrihizal fungi (AMF), which provide phosphorus and nitrogen to plants in degraded soil, to establish fungusroot interactions thus helping restore former reservoir areas after dam removal. They found that vegetation became mycorrihizal with or without AMF treatment, deeming it an ineffective restoration strategy. However, plots with mulch held more moisture, leading to greater vegetation cover, more native species, and significantly less runoff and erosion (Cook et al. 2011). Techniques such as these may be an effective management technique for restoring riparian communities, but more information is needed.

The plans and outcomes of managed re-vegetation have been documented for some dam removals in the Pacific Northwest. In their Small Dam Removal guide, the Oregon Watershed Enhancement Board (OWEB) states that managed re-vegetation is not necessary at sites where there is ample native vegetation upstream because the vegetation can be expected to recover naturally. They recommend managed re-vegetation only when there are significant invasive species populations upstream (Hoffert-Hay 2008). Chenoweth, Acker, and McHenry (2011) set forth a plan for the Elwha River revegetation with the main objectives of limiting invasive species, reestablishing ecosystem processes, and restoring native forests. They used reservoirs that had been drawn down prior to dam removal to examine whether vegetation was colonizing after a few months. On areas where the vegetation was recovering or had conditions that favored natural recovery, they did not perform active re-vegetation and only sometimes performed invasive species treatments. They assumed that sites within 50 meters of intact forests would recover without intervention as native seeds from the forest would disperse over 
that distance. In sites that were not recovering, they seeded with graminoids and forbs, and planted a variety of shrubs and trees (Chenoweth, Acker, and McHenry 2011). Since the removal of the Elwha dam and partial removal of Glines Canyon dam, the National Park Service (2013) has reported that there is a 97 percent survival rate among six of the species that were planted as early as fall 2011. The species with the highest mortality was Pseudotsuga menziesii (Douglas fir), at 36 percent, and the lowest mortality (1 percent) was among Populus trichocarpa (black cottonwood). The goals set forth by PacifiCorp (2011) in the re-vegetation plan for Condit Dam were to establish effective erosion control on sediments and stimulate a native plant community. They planned to plant trees and to re-vegetate sediments with a seed mix of 92 percent graminoids and forbs and 8 percent shrubs and trees. In upland and riparian areas, they seeded with a mix that had more shrubs and trees and planted trees. The main component in their seed mix was a non-native hybrid seed that could not reseed, and they hoped that this would be a good cover crop that would stabilize sediments, although no further work has been done to monitor the results of this effort (PacifiCorp 2011).

\section{Primary Succession in the Pacific Northwest}

Vegetation recovery after dam removal may resemble other highly disturbed sites in the Pacific Northwest that experienced primary succession. After the eruption of Mount St. Helens in 1980, multiple studies were done to examine vegetation on the new, barren landscape. Halpern and Harmon (1983) studied succession one year after a mudflow on the Muddy River that resulted from the eruption. They examined landscape factors in relation to vegetation, and found that canopy cover of herbs, shrubs and trees decreased with distance from the edge of the native forest. They also found that 
Pseudotsuga menziesii, Acer macrophyllum (bigleaf maple), and Tsuga heterophylla

(Western hemlock) were abundant and had a high survival in the first growing season.

Alnus rubra was the least abundant tree species but had the highest survival. Del Moral, Sandler, and Muerdter (2009) studied the same site after 28 growing seasons and also found that vegetation was strongly correlated with landscape factors of elevation, latitude, and distance from the forest. Pabst and Spies (2001) studied a debris flow along a river in Oregon to examine vegetation recovery. They found that weedy species increased in the third and fourth growing seasons after the disturbance, and native species either stayed the same or increased over time. They also found that two thirds of the species found in the second year after disturbance were still present eight years later. Alnus rubra showed a steady significant increase over time to 74 percent cover 10 years after the disturbance. They expected the weed stage to only last a few years, but forbs and graminoids actually dominated for 7 years on the bare sediment (Pabst and Spies 2001).

The existing literature is lacking in studies that assess an entire site, with repeated surveys, documenting both natural re-vegetation and the success of planted vegetation following dam removal. Additionally, there is a need for further information on the extent to which invasive species are colonizing dam removal sites, and whether they inhibit biodiversity as has been suggested to be the case. The success of managed planting has only recently been investigated and only at sites one year following dam removal. My research fills some of these gaps both spatially and temporally for an entire dam removal site in the Pacific Northwest. 


\section{STUDY AREA}

Hemlock Dam was an 8-meter high concrete structure built in 1935 by the Civilian Conservation Corps (CCC) (Figure 1) and subsequently removed in 2009. In 1903, one year after a huge fire, referred to as the Yacolt Burn, ravaged the future dam site, a lumber company set up a logging camp to capitalize on the burned forest and use the stream to transport logs to sawmills. They constructed a log splash dam on Trout Creek for this purpose. Shortly thereafter, in 1929, the lumber company went bankrupt, and the USFS bought the land. A large CCC camp was built on the site, and a concrete dam was built just downstream of the splash dam to supply water and hydroelectric power to the camp. In 1936, a fish ladder was constructed, and a picnic area with a boat launch and dock was established for the 11-acre Hemlock Lake. The dam was again modified in 1958 to provide irrigation water to the nearby Wind River Tree Nursery. When the nursery closed in 1996, the dam itself was no longer used, but the site continued to be a popular recreational day use facility managed by the USFS (Coffin 2011, Randle and Greimann 2004, Ryke 2005).

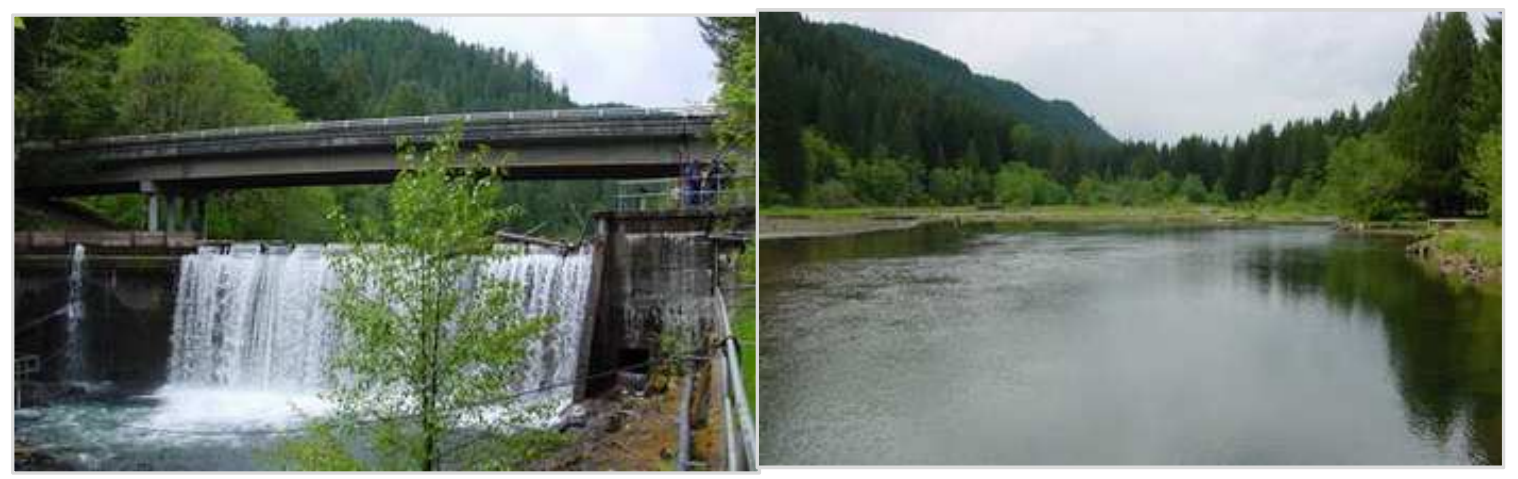

Figure 1. Hemlock Dam from below dam (left) and the reservoir as seen from bridge (right) (Randle and Greimann 2004). 
Adult steelhead returns to Trout Creek, which historically ranged from 350-700 fish per year, had dropped to as low as 10 fish per year by the 1990s (Coffin 2011). At that time the USFS began partnering with local agencies on several projects to restore the creek including introducing large woody debris to the stream channel, planting riparian vegetation, decommissioning roads in the watershed, and improving the fish ladder. However, sediment accumulation behind the dam led to shoaling, which is the creation of a sandbar, causing summer temperatures in the resulting shallow water of Hemlock Lake to approach lethal levels for fish. In addition, areas below the dam were starved of the sediment needed for maintaining aquatic spawning habitat. In 1998, the Lower Columbia Steelhead was listed as threatened under the Endangered Species Act, further highlighting the need for improvements to any possible steelhead habitat in the Columbia River system (Ryke 2005).

The USFS began assessing the possible habitat benefits of dam removal in 2004. They released a draft Environmental Impact Statement with five alternatives: take no action, remove the dam and let the river transport the accumulated sediments, remove the dam and build a channel through Hemlock Lake, keep the dam but fix deficiencies and remove the fish ladder, or keep the dam but fix deficiencies and repair the fish ladder (U.S. Forest Service (USFS) 2005). The Final Decision was made in 2005 to dredge sediments behind the dam, construct a channel near the pre-dam stream location, remove the dam, and make small changes to the Hemlock Recreation Site (Figure 2) (Ryke 2005). The work was completed in summer 2009. 

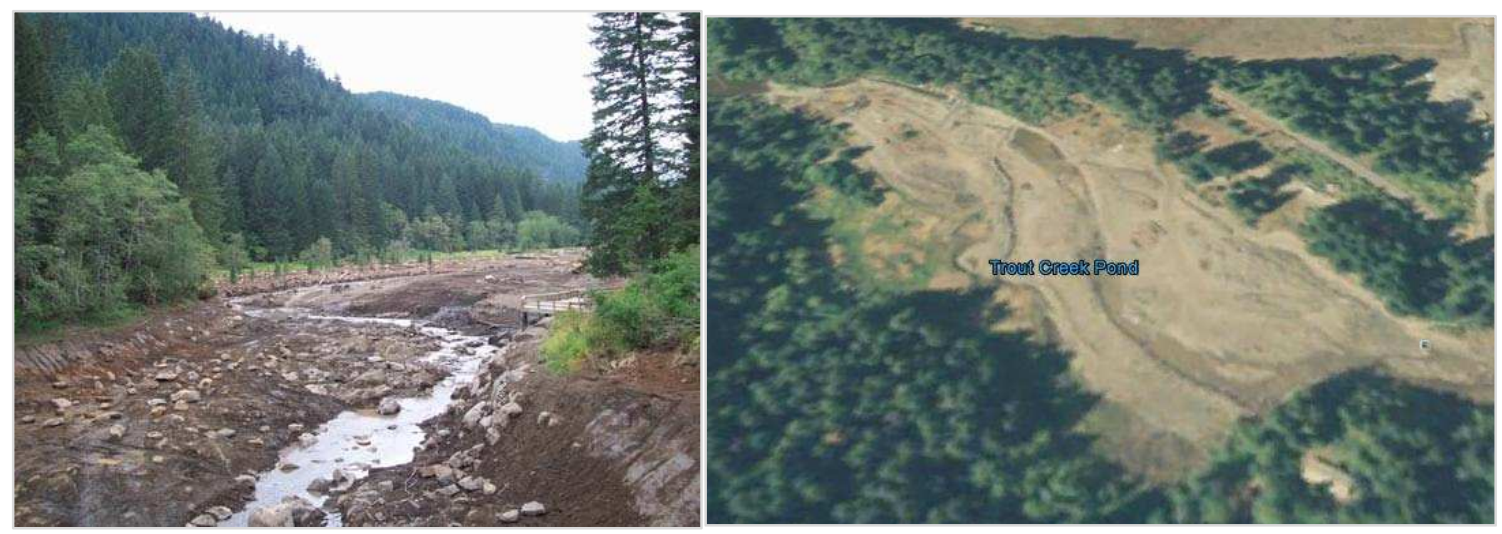

Figure 2. Former reservoir area immediately after dam removal, from bridge (Coffin 2011) and from a Google Earth image dated 10 September 2009 (right).

\section{Site Overview}

Hemlock Recreation Site (Hemlock) sits at an elevation of 335 meters and is comprised of the former reservoir bottom and the adjacent picnic area located near the unincorporated community of Stabler in Skamania County, Washington (Figure 3). The recreation area saddles Trout Creek, a perennial stream and major tributary of the Wind River. Trout Creek travels east and enters the Wind River 18 kilometers north of its own confluence with the Columbia River.

The Trout Creek Watershed drains 86 square kilometers. Hemlock is 2.9 kilometers upriver from the mouth of Trout Creek where the drainage basin size is 79 square kilometers (Randle and Greimann 2004). Elevation ranges from 260 to 1,158 meters (Coffin 2011) in the basin, and the area receives an average of 279 centimeters of precipitation per year (USFS 2005). The watershed is 99 percent federal owned forested land, with patches of private land near the confluence with the Wind River. The climate is characterized by cool, wet winters and warm, dry summers (Lower Columbia Fish Recovery Board (LCFRB) 2004). Trout Creek was placed on the Washington State 
303(d) list for high temperatures starting in 2002, which was primarily due to the warming effects of Hemlock Dam (Howard 2004).

The streamflow in Trout Creek generally follows the annual pattern of precipitation in this region with the highest flows, an average of 9.7 to 10.9 cubic meters per second (cms), occurring in November through February, and the lowest flows, at averages below $0.6 \mathrm{cms}$, in August and September (Randle and Greimann 2004). The soils are volcanic in origin and contain some colluvial material (Pacific Northwest Research Station 2003).

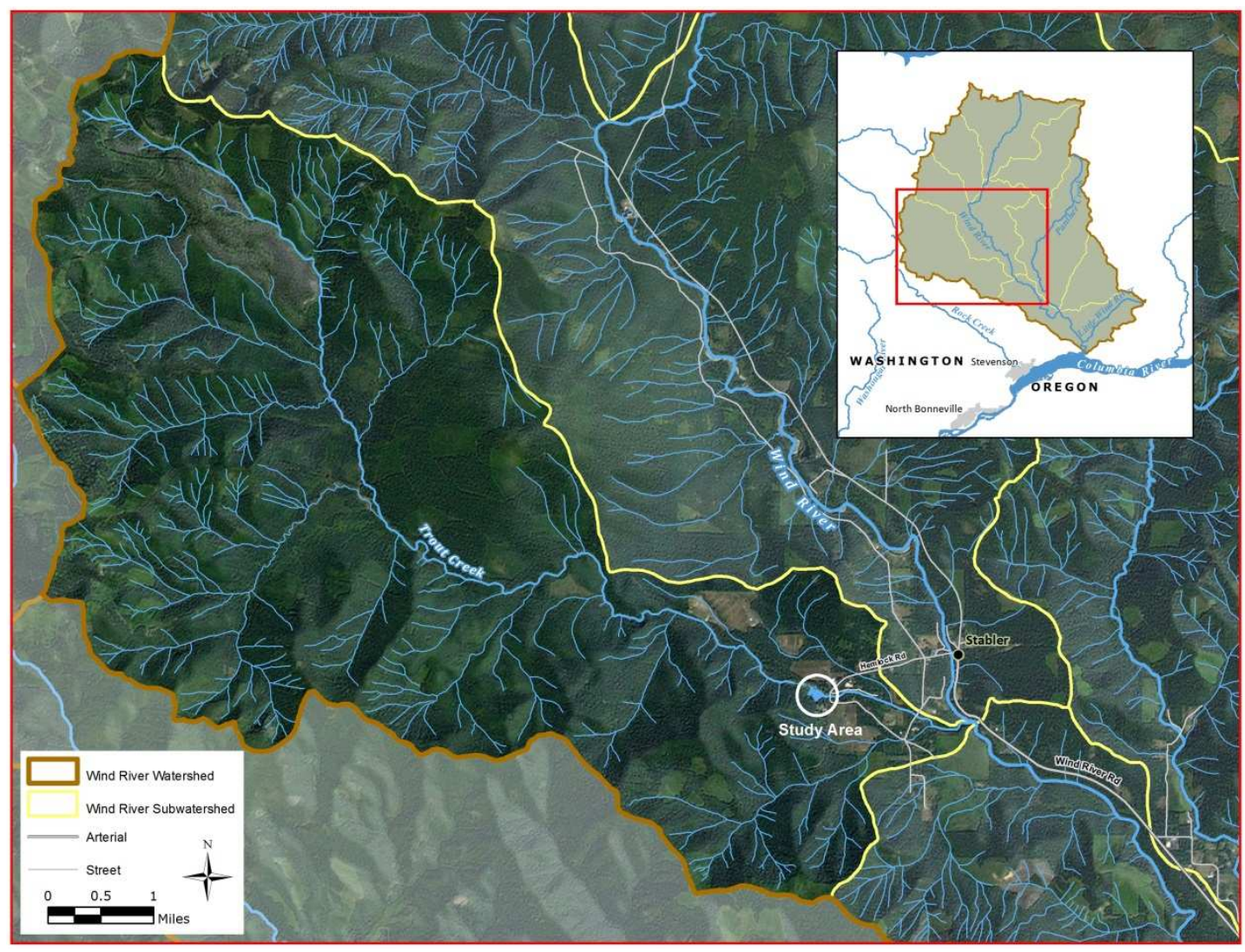

Figure 3. Watershed context of Hemlock Recreation Site. 
Most of the Wind River Watershed is in the Tsuga heterophylla vegetation zone, though some areas lie in the Abies amabilis (Pacific silver fir) zone (Franklin and Dyrness 1973). The dominant conifer species are Pseudotsuga menziesii and Tsuga heterophylla, though Thuja plicata (Western redcedar), Abies amabilis, and Abies grandis (grand fir) are also found here. Hardwoods include Alnus rubra, Acer macrophyllum, and Cornus nuttallii (Pacific dogwood). The shrub layer includes Acer circinatum (vine maple), Gaultheria shallon (salal), and Mahonia aquifolium (Oregon grape), while the forest floor is dominated by Polystichum munitum (Western swordfern). Fires are the main natural disturbance to vegetation in the watershed although logging was widespread in the past (LCFRB 2004, Pacific Northwest Research Station 2003).

Common large mammals found in the Wind River Watershed are elk and blacktailed deer, preyed on by species such as cougars, black bears, and coyotes. Threatened bird species such as spotted owls and bald eagles reside here, as do common small mammals such as Douglas squirrels and Townsend's chipmunks (LCFRB 2004, Pacific Northwest Research Station 2003). The only non-hatchery anadromous fish found in Trout Creek are summer and winter-run steelhead while rainbow trout and Eastern brook trout live in the creek year-round. Spring chinook has been introduced to the basin and is reared at the Carson National Fish Hatchery on the Wind River north of the confluence with Trout Creek (LCFRB 2004, Pacific Northwest Research Station 2003). Re-vegetation after Dam Removal

During dam removal, 62,000 cubic yards of sediment was found to have accumulated in the reservoir, 90 percent of which was sand-sized material. The removal left bare, sandy substrate devoid of vegetation. A re-vegetation plan was implemented to 
establish a diverse native plant community that would shade the creek and provide large woody debris for steelhead habitat. The two main objectives of active re-vegetation were to accelerate the succession process in order to more quickly establish a late-successional conifer riparian forest, and to prevent the spread of invasive species into newly exposed areas. The main species of concern was Phalaris arundinacea, which had invaded 4 acres of wetlands on the site prior to dam removal. Other invasive species found during dam decommissioning were Rubus laciniatus (cutleaf blackberry) and Rubus armeniacus (Himalayan blackberry), Cirsium arvense, Robinia pseudoacacia (black locust), and Cytisus scoparius (scotch broom). The USFS used many different planting methods, including dense planting to establish shade in order to eliminate invasive species establishment and using a variety of sources such as salvaged transplants, cuttings, bareroot, and containerized plants. Their five-year goals were to reduce weed cover to less than 20 percent and bare ground to less than 5 percent, to increase native trees and shrubs to greater than 50 percent, to document survival of planted species at greater than 70 percent, and to establish a species diversity that resembled nearby riparian forests (Ruchty 2011).

In the fall after the dam was removed, mature Pseudotsuga menziesii and large Populus trichocarpa and Salix lucida (Pacific willow) stakes were planted, Phalaris arundinacea mats were excavated or sprayed with herbicide, and a mix of native, locally-adapted grass species were seeded into the exposed areas. The following spring, nearly 23,000 plants were planted across the site, and another 3,670 were planted in 2011 (Table 1). Manual and herbicide treatment of invasive species was done for maintenance in both years (Ruchty 2011). 
Table 1. Species planted by USFS staff and volunteers in 2009 through 2011 (Ruchty 2011).

\begin{tabular}{|c|c|c|c|}
\hline & \multicolumn{3}{|c|}{ Planting Date } \\
\hline Species & Fall 2009 & Spring 2010 & October 2011 \\
\hline Deschampsia elongata (slender hairgrass) & $20 \mathrm{lbs} / \mathrm{acre}$ & & \\
\hline Bromus carinatus (mountain brome) & $10 \mathrm{lbs} / \mathrm{acre}$ & & \\
\hline Lolium multiflorum (annual ryegrass) & $20 \mathrm{lbs} / \mathrm{acre}$ & & \\
\hline Populus trichocarpa (black cottonwood) & Unknown & & \\
\hline Salix lucida (Pacific willow) & Unknown & & \\
\hline Alnus rubra (red alder) & & 10,000 & 2,530 \\
\hline Acer macrophyllum (bigleaf maple) & & 1,000 & \\
\hline Pseudotsuga menziesii (Douglas fir) & Unknown & 5,000 & \\
\hline Thuja plicata (Western redcedar) & & 2,172 & 1000 \\
\hline Tsuga heterophylla (Western hemlock) & & 2,084 & 1,000 \\
\hline Abies grandis (grand fir) & & 2,000 & \\
\hline Corus sericea (red osier dogwood) & & 649 & \\
\hline Sambucus racemosa (red elderberry) & & 35 & \\
\hline Physocarpus capitatus (Pacific ninebark) & & & 140 \\
\hline
\end{tabular}




\section{METHODS}

This study had two main objectives. The first objective was to assess vegetation changes from the third to fourth years following dam removal. The second objective was to determine whether landscape factors were influencing vegetation communities across the site in 2013. In order to meet these goals, I collected vegetation data at the same locations in both years and at additional quadrats in 2013. Additional environmental variables were measured in 2013 through field collection and through mapping of the quadrat locations in a geographic information system (GIS). The results were analyzed using various statistical techniques.

\section{Field Sampling Methods}

I began research at the Hemlock Dam site in June 2012 by establishing a sampling method. From a randomly selected starting point, transects were placed every 50 meters perpendicular to the stream, along the former reservoir area, which resulted in 8 transects. On the north side, transects were started furthest from the stream, while on the south side they began at the stream edge for ease of access. A number between 1 and 25 was chosen from a random number table to determine the starting point along each transect for the first one square meter quadrat; quadrats were then assessed every 25 meters beyond the starting point. A laser rangefinder was used to keep a consistent angle and distance from one quadrat to the next across the terrain. Sampling took place during four site visits in mid-July through the end of August.

In summer 2013, the same quadrat locations were resampled to examine changes in vegetation characteristics. To increase sample size for the purpose of correlating vegetation patterns to other environmental variables, a quadrat was added near each 
quadrat sampled in 2012. In order to maintain 25 meters of distance between transects, a random number between 1 and 25 was chosen, as was an angle 90 degrees to the east or west of the quadrat for the placement of a new quadrat. This second round of sampling was conducted over six site visits in early August through early September.

A total of 24 quadrats were sampled in 2012, and 48 were sampled in 2013 (Figures 4 and 5). After mapping the locations in a GIS, it was determined that some of the quadrat locations were outside the area of the former reservoir; hence, two of the quadrats sampled in 2012 and 2013 were removed as well as one of the additional quadrats sampled in 2013.

Vegetation was sampled using the Daubenmire Method outlined by the Bureau of Land Management National Applied Resource Sciences Center (1999). This method uses six separate cover classes to determine percent canopy cover for each species (Table 2). The method is appropriate for this research because it provides a quick and efficient means of assessing many quadrats across a site in order to estimate canopy cover. Each quadrat was viewed from above in determining the canopy coverage; species names by cover class were also recorded. Because there was overlapping coverage of different species in some quadrats, the canopy cover could exceed 100 percent. Bare ground cover, interpreted as the area with no plant stems or leaf litter at the ground level, was also estimated and recorded at each quadrat. GPS coordinates were collected using a Trimble GeoXM GPS receiver, and photos were taken using a digital camera. 
Table 2. Daubenmire Cover Classes used in this study.

\begin{tabular}{|c|c|}
\hline $\begin{array}{c}\text { Cover } \\
\text { Class }\end{array}$ & Range of Coverage \\
\hline 1 & $0-5 \%$ \\
\hline 2 & $5-25 \%$ \\
\hline 3 & $25-50 \%$ \\
\hline 4 & $50-75 \%$ \\
\hline 5 & $75-95 \%$ \\
\hline 6 & $95-100 \%$ \\
\hline
\end{tabular}

In addition to canopy cover, soil infiltration and chlorophyll were examined at all quadrats in 2013. Soil infiltration was measured as an indication of soil texture and the water available to plants. High infiltration rates indicate a sandy soil texture while lower rates are representative of clayey soils (Lowery et al. 1996). Clay-dominated soils hold nutrients well, whereas sandy soils tend to drain quickly and hold less water for plants thus limiting growth (Eash, Bratz, and Harpstead 2008, Jumpponen et al. 1999). Soil infiltration rate was measured using a double-ring infiltrometer with an outside ring diameter of $30.5 \mathrm{~cm}$ and an inside ring diameter of $15.2 \mathrm{~cm}$. One liter of water was poured into the outside ring to decrease the lateral spread of the one liter of water that was subsequently poured into the inside ring. The time it took for the water to completely infiltrate in the inner ring was recorded. At wetland sites with standing water no value was recorded. This method was used because it was rapid and could be done by one person with relatively little equipment (Brouwer et al. 1988). An infiltration rate, in centimeters per hour, was then calculated for each quadrat.

Chlorophyll allows plants to convert sunlight into chemical energy. Chlorophyll values can indicate nitrogen status, water stress, and other plant stresses (Zhu, Tremblay, 
and Yinli 2012). Chlorophyll was measured using a handheld atLEAF+ chlorophyll meter. The goal was to collect a reading for one species, near each quadrat, across the site in order to assess how the same species was performing under the varying site conditions. Alnus rubra trees were determined to be a good species for this study as they were well distributed across the site. The average chlorophyll reading from three different leaves at breast height was recorded for the Alnus rubra either within the quadrat or closest to each quadrat to a maximum distance of five meters.

Elevation may influence where and how vegetation establishes on reservoir sediments. Elevation, depicted as height above the active stream channel, plays a role in the composition of riparian vegetation communities (Bendix 1994, Rot, Naiman, and Bilby 2000). Water stress on terraces at higher elevations above the water table may limit the number of species that can establish and survive there (Chenoweth, Acker, and McHenry 2011). Elevation at each quadrat was determined from topographical survey data collected at the site in 2013 by USFS using a total station. The planimetric survey produced a point cloud with an arbitrary local coordinate system and elevations. A GPS was used to find the actual coordinates of a USFS control point from their survey, which allowed for conversion of the points to a real world projection (UTM NAD 83). In ArcGIS, a spatial join was used to give each quadrat the elevation of the nearest survey point.

Similar to elevation, sites nearer to the stream may have greater access to the water table, floodplain nutrients, and seeds dispersed by water. However, sites further from the stream at higher elevations will have greater access to seeds from the native forest surrounding the reservoir. To calculate distance from each quadrat to the stream, 
the center line of the stream was digitized in ArcGIS based on aerial ESRI ArcMap photos. The Near tool was used to find distance from each quadrat to the stream.

\section{Data Analysis}

Each plant was identified to the species level using various field guides, as well as with assistance from botanists with the USFS and Oregon State and Washington State Extension offices (DiTomaso, Healy, and Rejmanek 2007, Pojar, Mackinnon, and Alaback 1994, Weinmann et al. 1984, Taylor 1990). The Daubenmire method allows for calculation of canopy cover, frequency, and species composition for each plant and each quadrat. Percent canopy cover was calculated by multiplying the number of times the species was found in each cover class by the midpoint of each class, summing these numbers, and dividing by the number of quadrats sampled. To determine percent frequency, the number of occurrences of the species was divided by the total number of quadrats and multiplied by 100 . The species composition was calculated by dividing the percent canopy cover of the species by the total canopy cover of all plant species, which results in a relative canopy cover for each species (Bureau of Land Management National Applied Resource Sciences Center 1999).

Each plant species was then classified into various groups based on growth habit as documented in the United States Department of Agriculture Natural Resources Conservation Service Plants Database. Each plant was classified as graminoid (grasslike, including rushes and sedges), forb (non-grass, herbaceous flowering plant without woody tissue), shrub (perennial, woody, multi-stem shorter than 4 to 5 meters), or tree (perennial, woody, single-trunk taller than 5 meters). The same database was used to determine whether plants were native or introduced (U.S. Department of Agriculture 
Natural Resources Conservation Board (NRCS) 2014). The Washington State 2013

Noxious Weeds List was used to identify noxious plants, which are non-native species that negatively affect crops, ecosystems, or fish and wildlife habitat (Washington State Noxious Weed Control Board 2013). If a plant was introduced but did not have the characteristics of a noxious species, it was classified simply as a weed. The USFS planting list was used to determine whether a plant was a volunteer (established on its own) or was planted (Ruchty 2011). These classification groups were then applied to the quadrats. For each quadrat, canopy cover by each of the above groups was calculated. A calculation of canopy cover for these groups was also completed for the entire site.

Finally, the Simpson's Index was computed for each quadrat sampled (Simpson 1949). This index incorporates species richness, which refers to how many species were found, and evenness, or how similar the canopy covers of each species are. It was used here to give an index, based on canopy cover, for assessing whether species diversity was increasing or decreasing between years. The Simpson's Index ranges from 0 to 1 for any quadrat, with higher numbers indicating higher richness and evenness.

The first goal of analysis was to assess the differences in vegetation characteristics between 2012 and 2013. To determine the changes in canopy cover, species composition, and species frequency, a Wilcoxon signed-rank test was used to show how many species had an increase or decrease from one year to the next. A rankabundance curve was also created to provide a visual assessment of how canopy cover was distributed across the species. For the quadrat data by plant type, the data were checked for normality. Because there were many zeroes in the data, 0.5 was added to each number prior to applying a log-transformation and conducting a paired t-test. 
The second goal was to determine whether environmental factors were influencing the kinds of plants found in each quadrat. For this analysis, the 2013 data were used as the larger number of quadrats provided for a more robust test. SPSS was used to determine the Pearson Correlation Coefficient for each of the classification groups (graminoid, forb, shrub, tree, native, non-native, noxious, volunteer, planted, bare ground) in relation to other groups and the environmental variables of elevation, distance from stream, infiltration rate, and chlorophyll levels. The significance threshold for all tests was set at values less than 0.05 . 


\section{RESULTS}

Each of the 22 quadrats that were sampled in both years was given a name that reflected the transect and quadrat order, ranging from B1Q1 to B8Q4. Each of the additional 23 quadrats sampled in 2013 was named with an additional $\mathrm{R}$ to reflect the random number offset, therefore the names ranged from B1Q1R-B8Q4R (Figure 4). The vegetation data collected at each of these quadrats was examined in order to reveal

differences between years and correlations of the vegetation data with the measured environmental variables. 


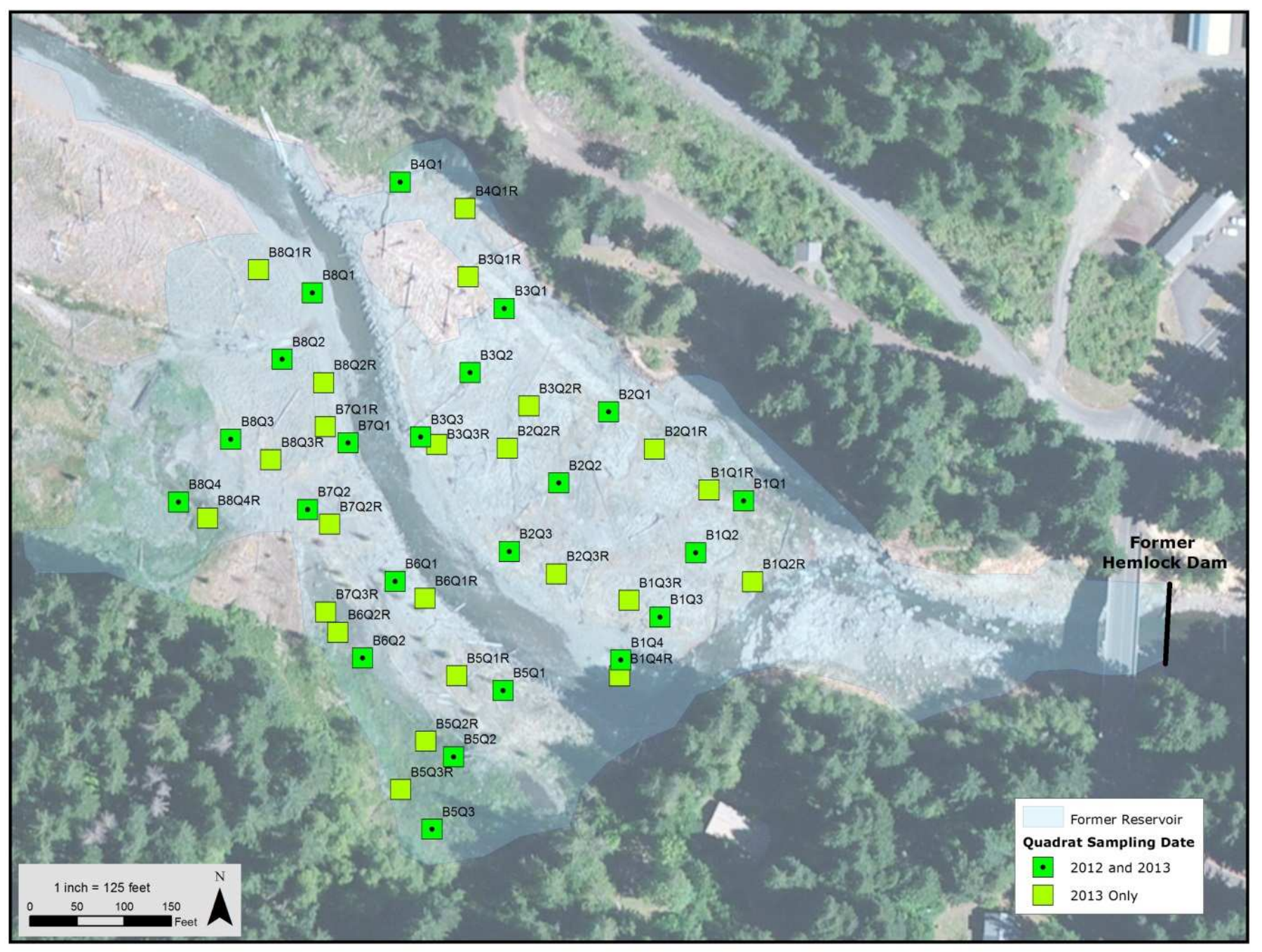

Figure 4. Quadrat locations at the study site. 

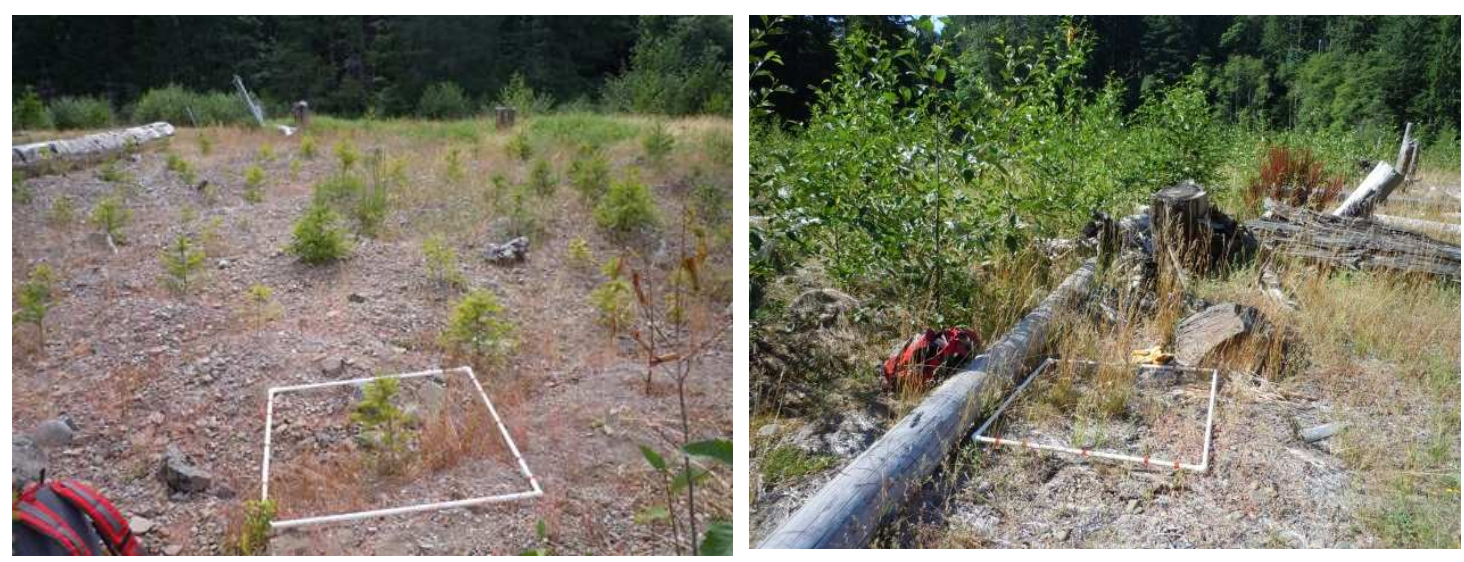

Figure 5. Examples of quadrats sampled at the site.

\section{Differences between Years}

In the original 22 quadrats, 33 species were found in 2012 and 38 in 2013 (Table 3). A total of 47 species were found in 2013 in the 45 quadrats (Table 4). The total canopy cover of species on the site at the 22 quadrats was $57 \%$ in 2012 , and increased to $68 \%$ in 2013 . When taking into account the additional quadrats in 2013 , the total canopy was only slightly higher at 69\%. Two species, Lotus purshianus (Spanish clover) and Alnus rubra, had much higher canopy covers than other species in 2012 and 2013. In 2012, Lotus purshianus also had the highest frequency. In 2013, Epilobium brachycarpum (tall annual willowherb) was found in the most quadrats, and when the other quadrats were added Hypochaeris radicata (hairy cat's ear) was found in an equally high number of quadrats. 
Table 3. Species and their abundance, ranked by canopy cover, in the 22 quadrats sampled.

\begin{tabular}{|c|c|c|c|c|c|c|c|c|c|c|c|}
\hline \multirow{2}{*}{ Common Name } & \multirow{2}{*}{ Scientific Name } & \multirow{2}{*}{ Duration } & \multirow{2}{*}{$\begin{array}{l}\text { Native } \\
\text { Status }\end{array}$} & \multirow{2}{*}{ Planted? } & \multirow{2}{*}{$\begin{array}{c}\text { Growth } \\
\text { Habit }\end{array}$} & \multicolumn{2}{|c|}{$\begin{array}{c}\text { Percent } \\
\text { Canopy Cover }\end{array}$} & \multicolumn{2}{|c|}{$\begin{array}{c}\text { Percent } \\
\text { Frequency }\end{array}$} & \multicolumn{2}{|c|}{$\begin{array}{c}\text { Species } \\
\text { Composition } \\
\end{array}$} \\
\hline & & & & & & 2012 & 2013 & 2012 & 2013 & 2012 & 2013 \\
\hline Red alder & Alnus rubra & Perennial & Native & Yes & Tree & 6.3 & 11.9 & 31.8 & 40.9 & 11.0 & 17.4 \\
\hline Reed canarygrass & Phalis arundinacea & Perennial & Noxious & No & Graminoid & 4.9 & 2.8 & 22.7 & 27.3 & 8.6 & 4.2 \\
\hline Riverbank lupine & Lupinus rivularis & Perennial & Native & No & Forb & 4.3 & 6.8 & 18.2 & 13.6 & 7.6 & 10.0 \\
\hline $\begin{array}{l}\text { Tall annual } \\
\text { willowherb }\end{array}$ & $\begin{array}{l}\text { Epilobium } \\
\text { brachycarpum }\end{array}$ & Annual & Native & No & Forb & 4.0 & 3.6 & 50.0 & 59.1 & 7.0 & 5.3 \\
\hline Daggerleaf rush & Juncus ensifolius & Perennial & Native & No & Graminoid & 3.9 & 2.8 & 4.5 & 4.5 & 6.8 & 4.2 \\
\hline Mountain brome & Bromus carinatus & Annual & Native & Yes & Graminoid & 3.5 & 3.0 & 50.0 & 50.0 & 6.2 & 4.3 \\
\hline Slender hairgrass & Deschampsia elongata & Perennial & Native & Yes & Graminoid & 2.7 & 0.9 & 22.7 & 13.6 & 4.8 & 1.3 \\
\hline Watson's willowherb & Epilobium watsonii & Perennial & Native & No & Forb & 2.5 & 2.7 & 13.6 & 22.7 & 4.4 & 4.0 \\
\hline White clover & Trifolium repens & Perennial & Weed & No & Forb & 1.9 & 0.1 & 13.6 & 4.5 & 3.4 & 0.2 \\
\hline European bur-reed & Sparganium emersum & Perennial & Native & No & Graminoid & 1.4 & 0.8 & 9.1 & 9.1 & 2.4 & 1.2 \\
\hline Hairy cat's ear & Hypochaeris radicata & Perennial & Noxious & No & Forb & 1.3 & 3.1 & 27.3 & 54.5 & 2.2 & 4.5 \\
\hline Douglas fir & Pseudotsuga menziesii & Perennial & Native & Yes & Tree & 0.9 & 2.0 & 13.6 & 13.6 & 1.6 & 3.0 \\
\hline Birdsfoot trefoil & Lotus corniculatus & Perennial & Weed & No & Forb & 0.8 & 1.6 & 9.1 & 18.2 & 1.4 & 2.3 \\
\hline Cattail & Typha latifolia & Perennial & Native & No & Graminoid & 0.8 & 0 & 9.1 & 0 & 1.4 & 0 \\
\hline Kentucky bluegrass & Poa pratensis & Perennial & Weed & No & Graminoid & 0.7 & 0.2 & 4.5 & 9.1 & 1.2 & 0.3 \\
\hline Jointed rush & Juncus articulatus & Perennial & Native & No & Graminoid & 0.2 & 1.4 & 9.1 & 9.1 & 0.4 & 2.0 \\
\hline Common smartweed & Polygonum persicaria & Annual & Weed & No & Forb & 0.2 & 0.1 & 9.1 & 4.5 & 0.4 & 0.2 \\
\hline Devil's beggartick & Bidens frondosa & Annual & Native & No & Forb & 0.2 & 0.8 & 9.1 & 9.1 & 0.4 & 1.2 \\
\hline St John's wort & Hypericum perforatum & Perennial & Noxious & No & Forb & 0.1 & 0.9 & 4.5 & 13.6 & 0.2 & 1.3 \\
\hline
\end{tabular}




\begin{tabular}{|c|c|c|c|c|c|c|c|c|c|c|c|}
\hline \multirow{2}{*}{ Common Name } & \multirow{2}{*}{ Scientific Name } & \multirow{2}{*}{ Duration } & \multirow{2}{*}{$\begin{array}{l}\text { Native } \\
\text { Status }\end{array}$} & \multirow{2}{*}{ Planted? } & \multirow{2}{*}{$\begin{array}{l}\text { Growth } \\
\text { Habit }\end{array}$} & \multicolumn{2}{|c|}{$\begin{array}{c}\text { Percent } \\
\text { Canopy Cover }\end{array}$} & \multicolumn{2}{|c|}{$\begin{array}{c}\text { Percent } \\
\text { Frequency }\end{array}$} & \multicolumn{2}{|c|}{$\begin{array}{c}\text { Species } \\
\text { Composition }\end{array}$} \\
\hline & & & & & & 2012 & 2013 & 2012 & 2013 & 2012 & 2013 \\
\hline Prickly lettuce & Lactuca serriola & Annual & Weed & No & Forb & 0.1 & 0.2 & 4.5 & 9.1 & 0.2 & 0.3 \\
\hline Oxeye daisy & $\begin{array}{l}\text { Chrysanthemum } \\
\text { leucanthemum }\end{array}$ & Perennial & Noxious & No & Forb & 0.1 & 0.1 & 4.5 & 4.5 & 0.2 & 0.2 \\
\hline Common groundsel & Senecio vulgaris & Annual & Noxious & No & Forb & 0.1 & 0.3 & 4.5 & 13.6 & 0.2 & 0.5 \\
\hline Cooley's hedge nettle & Stachys cooleyae & Perennial & Native & No & Forb & 0.1 & 0.1 & 4.5 & 4.5 & 0.2 & 0.2 \\
\hline Pacific willow & Salix lucida & Perennial & Native & Yes & Shrub & 0.1 & 0.7 & 4.5 & 4.5 & 0.2 & 1.0 \\
\hline Thimbleberry & Rubus parviflorus & Perennial & Native & No & Shrub & 0.1 & 0.7 & 4.5 & 4.5 & 0.2 & 1.0 \\
\hline Canada thistle & Cirsium arvense & Perennial & Noxious & No & Forb & 0.1 & 0 & 4.5 & 0 & 0.2 & 0 \\
\hline Field mint & Mentha arvensis & Perennial & Native & No & Forb & 0.1 & 0 & 4.5 & 0 & 0.2 & 0 \\
\hline Marsh forget-me-not & Myosotis scorpioides & Perennial & Weed & No & Forb & 0.1 & 1.7 & 4.5 & 4.5 & 0.2 & 2.5 \\
\hline Cleavers & Galium aparine & Annual & Weed & No & Forb & 0 & 0.1 & 0 & 4.5 & 0 & 0.2 \\
\hline Bigleaf maple & Acer macrophyllum & Perennial & Native & Yes & Tree & 0 & 0.1 & 0 & 4.5 & 0 & 0.2 \\
\hline Tiny trumpet & Collomia linearis & Annual & Native & No & Forb & 0 & 0.2 & 0 & 9.1 & 0 & 0.3 \\
\hline Common dandelion & Taraxacum officinale & Perennial & Weed & No & Forb & 0 & 0.2 & 0 & 9.1 & 0 & 0.3 \\
\hline Needle spikerush & Eleocharis acicularis & Perennial & Native & No & Graminoid & 0 & 1.4 & 0 & 9.1 & 0 & 2.0 \\
\hline Musk flower & Mimulus moschatus & Perennial & Native & No & Forb & 0 & 0.7 & 0 & 4.5 & 0 & 1.0 \\
\hline Annual ryegrass & Lolium multiflorum & Perennial & Native & Yes & Graminoid & 0 & 0.1 & 0 & 4.5 & 0 & 0.2 \\
\hline Blue wild rye & Elymus glaucus & Perennial & Native & No & Graminoid & 0 & 0.1 & 0 & 4.5 & 0 & 0.2 \\
\hline
\end{tabular}


Table 4. Species and their abundance, ranked by canopy cover, in the 45 quadrats sampled in 2013.

\begin{tabular}{|c|c|c|c|c|c|c|c|c|}
\hline Common Name & Scientific name & Duration & $\begin{array}{l}\text { Native } \\
\text { Status }\end{array}$ & Planted? & $\begin{array}{c}\text { Growth } \\
\text { Habit }\end{array}$ & $\begin{array}{c}\text { Percent } \\
\text { Canopy Cover }\end{array}$ & $\begin{array}{c}\text { Percent } \\
\text { Frequency }\end{array}$ & $\begin{array}{c}\text { Species } \\
\text { Composition } \\
\end{array}$ \\
\hline Spanish clover & Lotus purshianus & Annual & Native & No & Forb & 13.7 & 48.9 & 19.6 \\
\hline Red alder & Alnus rubra & Perennial & Native & Yes & Tree & 13.3 & 35.6 & 19.2 \\
\hline Riverbank lupine & Lupinus rivularis & Perennial & Native & No & Forb & 5.6 & 13.3 & 8.1 \\
\hline Hairy cat's ear & Hypochaeris radicata & Perennial & Noxious & No & Forb & 4.3 & 53.3 & 6.2 \\
\hline Reed canarygrass & Phalis arundinacea & Perennial & Noxious & No & Graminoid & 4.3 & 24.4 & 6.2 \\
\hline Tall annual willowherb & Epilobium brachycarpum & Annual & Native & No & Forb & 2.9 & 53.3 & 4.2 \\
\hline European bur-reed & Sparganium emersum & Perennial & Native & No & Graminoid & 2.6 & 8.9 & 3.8 \\
\hline Mountain brome & Bromus carinatus & Annual & Native & Yes & Graminoid & 2.3 & 46.7 & 3.3 \\
\hline $\begin{array}{l}\text { Soft- or hard-stemmed } \\
\text { bulrush }\end{array}$ & Schoenoplectus sp. & Perennial & Native & No & Graminoid & 1.8 & 6.7 & 2.6 \\
\hline Douglas fir & Pseudotsuga menziesii & Perennial & Native & Yes & Tree & 1.7 & 13.3 & 2.5 \\
\hline Smallfruit bulrush & Scirpus microcarpus & Perennial & Native & No & Graminoid & 1.7 & 4.4 & 2.5 \\
\hline Daggerleaf rush & Juncus ensifolius & Perennial & Native & No & Graminoid & 1.4 & 4.4 & 2.1 \\
\hline Small creeping buttercup & Ranunculus flammula & Perennial & Native & No & Forb & 1.2 & 4.4 & 1.7 \\
\hline St John's wort & Hypericum perforatum & Perennial & Noxious & No & Forb & 1.1 & 20.0 & 1.5 \\
\hline Birdsfoot trefoil & Lotus corniculatus & Perennial & Weed & No & Forb & 1.1 & 20.0 & 1.5 \\
\hline Needle spikerush & Eleocharis acicularis & Perennial & Native & No & Graminoid & 1.0 & 6.7 & 1.4 \\
\hline Creeping spikerush & Eleocharis fallax & Perennial & Native & No & Graminoid & 0.8 & 2.2 & 1.2 \\
\hline Marsh forget-me-not & Myosotis scorpioides & Perennial & Weed & No & Forb & 0.8 & 2.2 & 1.2 \\
\hline Jointed rush & Juncus articulatus & Perennial & Native & No & Graminoid & 0.7 & 4.4 & 1.0 \\
\hline Prickly lettuce & Lactuca serriola & Annual & Weed & No & Forb & 0.6 & 11.1 & 0.8 \\
\hline Slender hairgrass & Deschampsia elongata & Perennial & Native & Yes & Graminoid & 0.5 & 8.9 & 0.7 \\
\hline
\end{tabular}

$\stackrel{\omega}{N}$ 


\begin{tabular}{|c|c|c|c|c|c|c|c|c|}
\hline Common Name & Scientific name & Duration & $\begin{array}{l}\text { Native } \\
\text { Status }\end{array}$ & Planted? & $\begin{array}{c}\text { Growth } \\
\text { Habit }\end{array}$ & $\begin{array}{c}\text { Percent } \\
\text { Canopy Cover }\end{array}$ & $\begin{array}{c}\text { Percent } \\
\text { Frequency }\end{array}$ & $\begin{array}{c}\text { Species } \\
\text { Composition }\end{array}$ \\
\hline Common smartweed & Polygonum persicaria & Annual & Weed & No & Forb & 0.4 & 4.4 & 0.6 \\
\hline Devil's beggartick & Bidens frondosa & Annual & Native & No & Forb & 0.4 & 4.4 & 0.6 \\
\hline Pacific willow & Salix lucida & Perennial & Native & Yes & Shrub & 0.4 & 4.4 & 0.6 \\
\hline Common groundsel & Senecio vulgaris & Annual & Noxious & No & Forb & 0.3 & 13.3 & 0.5 \\
\hline Thimbleberry & Rubus parviflorus & Perennial & Native & No & Shrub & 0.3 & 2.2 & 0.5 \\
\hline Tiny trumpet & Collomia linearis & Annual & Native & No & Forb & 0.3 & 13.3 & 0.5 \\
\hline Musk flower & Mimulus moschatus & Perennial & Native & No & Forb & 0.3 & 2.2 & 0.5 \\
\hline Western brackenfern & Pteridium aquilinum & Perennial & Native & No & Forb & 0.3 & 2.2 & 0.5 \\
\hline Common dandelion & Taraxacum officinale & Perennial & Weed & No & Forb & 0.2 & 6.7 & 0.2 \\
\hline Oxeye daisy & $\begin{array}{l}\text { Chrysanthemum } \\
\text { leucanthemum }\end{array}$ & Perennial & Noxious & No & Forb & 0.1 & 4.4 & 0.2 \\
\hline White clover & Trifolium repens & Perennial & Weed & No & Forb & 0.1 & 4.4 & 0.2 \\
\hline Cleavers & Galium aparine & Annual & Weed & No & Forb & 0.1 & 4.4 & 0.2 \\
\hline Kentucky bluegrass & Poa pratensis & Perennial & Weed & No & Graminoid & 0.1 & 4.4 & 0.2 \\
\hline Cooley's hedge nettle & Stachys cooleyae & Perennial & Native & No & Forb & 0.1 & 2.2 & 0.1 \\
\hline Cattail & Typha latifolia & Perennial & Native & No & Graminoid & 0.1 & 2.2 & 0.1 \\
\hline Marsh cudweed & Gnaphalium uliginosum & Annual & Weed & No & Forb & 0.1 & 2.2 & 0.1 \\
\hline Bigleaf maple & Acer macrophyllum & Perennial & Native & Yes & Tree & 0.1 & 2.2 & 0.1 \\
\hline Curly dock & Rumex crispus & Perennial & Weed & No & Forb & 0.1 & 2.2 & 0.1 \\
\hline Western red cedar & Thuja plicata & Perennial & Native & Yes & Tree & 0.1 & 2.2 & 0.1 \\
\hline Soft rush & Juncus effusus & Perennial & Native & No & Graminoid & 0.1 & 2.2 & 0.1 \\
\hline Annual ryegrass & Lolium multiflorum & Perennial & Native & Yes & Graminoid & 0.1 & 2.2 & 0.1 \\
\hline Blue wild rye & Elymus glaucus & Perennial & Native & No & Graminoid & 0.1 & 2.2 & 0.1 \\
\hline Common chickweed & Stellaria media & Annual & Weed & No & Forb & 0.1 & 2.2 & 0.1 \\
\hline Cotton-batting cudweed & Gnaphalium stramineum & Annual & Native & No & Forb & 0.1 & 2.2 & 0.1 \\
\hline
\end{tabular}


The differences in mean values of species attributes were not significantly different. However, most species showed change across the years, either increasing or decreasing (Table 5). For canopy cover, 24 species increased in total cover in 2013 while 13 species decreased; four species showed no net change. For species frequency, about half of the species were found in more quadrats in 2013 than 2012; a third were found in the same number of quadrats while the rest were found in less quadrats. There were only slightly more species that had a higher species composition in 2013 , but none of the species had the same composition across the years.

Table 5. Outcome of Wilcoxon Signed Ranks Test performed on Daubenmire results.

\begin{tabular}{|l|c|c|c|}
\cline { 2 - 4 } \multicolumn{1}{c|}{} & $\begin{array}{c}\text { Negative Ranks } \\
(2013-2012<0)\end{array}$ & $\begin{array}{c}\text { Positive Ranks } \\
(2013-2012>0)\end{array}$ & $\begin{array}{c}\text { Ties } \\
(2013-2012=0)\end{array}$ \\
\hline Canopy Cover & 13 & 24 & 4 \\
\hline Species Frequency & 9 & 19 & 13 \\
\hline Species Composition & 19 & 22 & 0 \\
\hline
\end{tabular}

The rank-abundance curve charts the abundance of each species as ranked in order of highest (1) to lowest (41) canopy cover. A lognormal trendline was fit to the data (Figure 6). If the slope of the line is steep, it indicates that the site is dominated by a few species. If the slope is shallow, there is more evenness across species as a high number have a similar canopy cover. In this case, the curve shows a very steep slope that gradually levels off to an almost horizontal line. This indicates that the site is in fact dominated by a few species and that many species have the same low canopy cover. The 
slope of the lognormal trendline is steeper in 2013, indicating a decrease in evenness in the fourth year after dam removal.

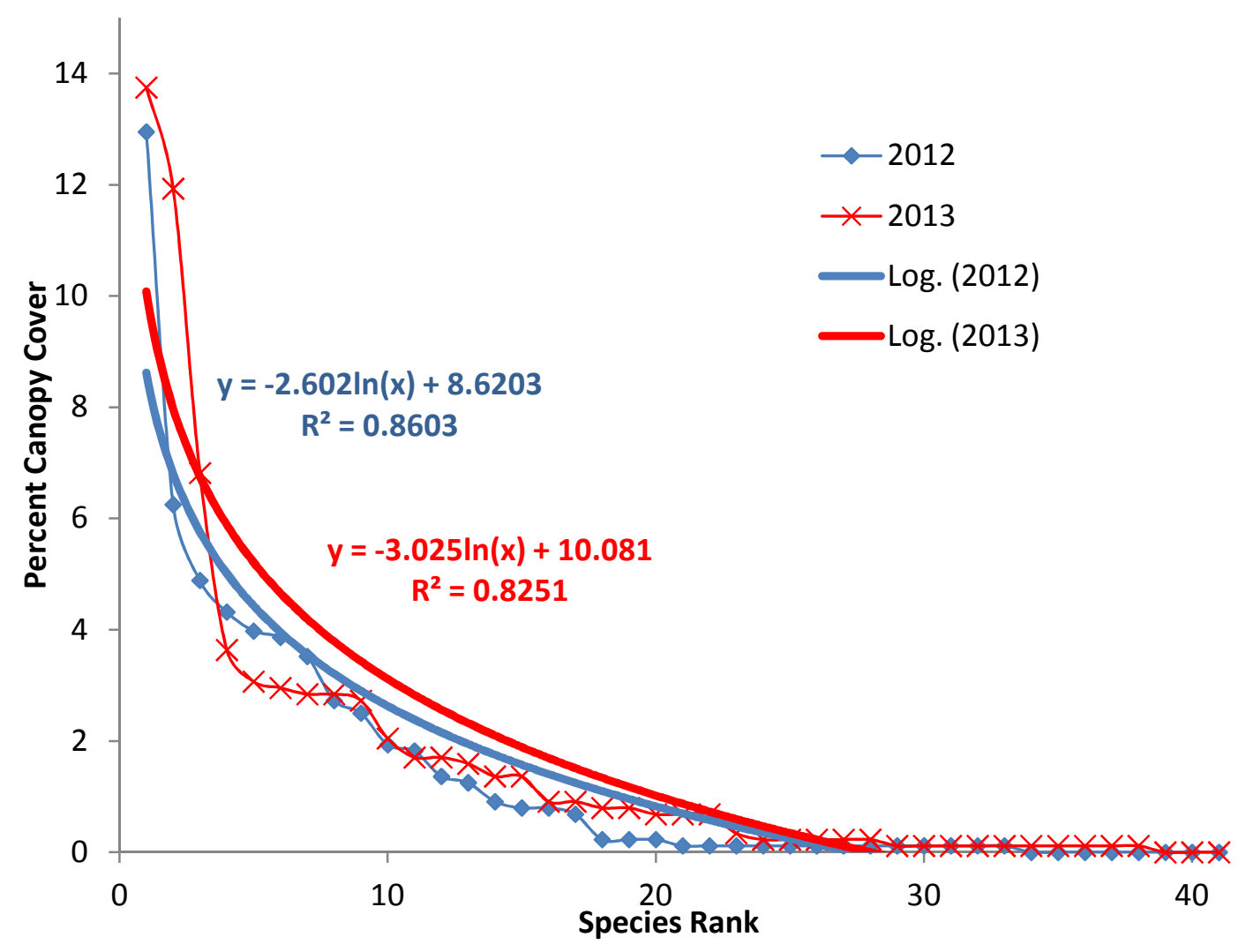

Figure 6. Rank abundance curve fit with a lognormal trendline.

The paired t-tests showed significant differences in two plant classification groups across the quadrats (Table 6). There was a significant increase in canopy cover of native species in the quadrats from 2012 to 2013; the mean native canopy cover increased from 46.1 to 56.7 percent between these years. There was also a significant increase in total mean canopy cover across the quadrats; it increased from 56.7 to 68.4 percent between these years. Two other variables, forb and tree canopy, had significance levels just 
slightly higher than the 0.05 cutoff, implying that the increase in means from 2012 to 2013 was marginally significant. Statistical tests for canopy cover of shrubs and weeds were not run due to the fact that so few species were found in these two classification groups. Because some of the changes were dynamic, if not necessarily significant, more detailed results are presented.

Table 6. Results of paired t-tests by plant classifications.

\begin{tabular}{|l|c|c|}
\cline { 2 - 3 } \multicolumn{1}{c|}{} & $\begin{array}{c}\mathrm{t}- \\
\text { statistic }\end{array}$ & Significance \\
\hline Species richness & -1.839 & 0.08 \\
\hline Simpson's Index & 0.067 & 0.95 \\
\hline Total Canopy Cover & -2.663 & $\mathbf{0 . 0 2}$ \\
\hline Bare Ground Cover & -0.826 & 0.42 \\
\hline
\end{tabular}

Canopy Cover by Species Classification Groups

\begin{tabular}{|l|c|c|}
\hline Graminoid & 1.357 & 0.19 \\
\hline Forb & -1.996 & 0.06 \\
\hline Tree & -2.016 & 0.06 \\
\hline Native & -2.335 & $\mathbf{0 . 0 3}$ \\
\hline Non-Native & -0.848 & 0.41 \\
\hline Noxious & -0.769 & 0.45 \\
\hline Planted & -1.374 & 0.18 \\
\hline Volunteer & -1.811 & 0.09 \\
\hline
\end{tabular}

Species richness increased in 2013 by 5 species (Table 7). The maximum number of species in any quadrat increased to 10, and the mean and standard deviation increased slightly. The quadrat with the highest number of species was B3Q2, which is on the north side of the creek approximately halfway between the picnic area and the stream (Figure 4). The lowest species richness occurred at B7Q1R near the stream on the south 
side of the river and was occupied only by Lupinus rivularis (riverbank lupine).

Doubling the number of quadrats in 2014 resulted in just 25 percent more species. The minimum in only one quadrat decreased, and the mean and standard deviation shifted only slightly. The mean Simpson's Index was the same in 2012 and 2013, and decreased by a small amount when taking into account all quadrats in 2013 .

Table 7. Species richness and Simpson's Index across the site.

\begin{tabular}{|l|c|c|c|}
\cline { 2 - 4 } \multicolumn{1}{c|}{} & \multicolumn{2}{c|}{ Original quadrats } & 2013 with additional \\
\cline { 2 - 4 } \multicolumn{1}{c|}{} & 2012 & 2013 & quadrats* \\
\hline Total Canopy Cover (percent) & 57 & 68 & 69 \\
\hline Total Species & 33 & 38 & 47 \\
\hline
\end{tabular}

By Quadrat

\begin{tabular}{|l|c|c|c|}
\hline Minimum & 2 & 2 & 1 \\
\hline Maximum & 8 & 10 & 10 \\
\hline Mean & 4.6 & 5.5 & 5.2 \\
\hline Standard Deviation & 1.7 & 2 & 2.1 \\
\hline Mean Simpson's Index & 0.57 & 0.57 & 0.53 \\
\hline
\end{tabular}

*2013 data of 45 quadrats used for reference only, not for statistical analysis.

Graminoid canopy cover decreased from 2012 to 2013, although the number of graminoid species increased (Table 8). The average number of grasses in each quadrat was approximately 1.5 across both years, and some of the wetland quadrats had as many as 6 grass species. Three new grass species were found in the additional quadrats in 2013. Out of all the grasses on the site, only one grass species was noxious, one was introduced but not noxious, and the remaining were native. 
Table 8. Distribution of growth habit of species found on site.

\begin{tabular}{|c|c|c|c|c|c|c|}
\hline & \multicolumn{4}{|c|}{ Original quadrats } & \multirow{2}{*}{\multicolumn{2}{|c|}{$\begin{array}{c}2013 \text { with } \\
\text { additional quadrats }\end{array}$}} \\
\hline & \multicolumn{2}{|c|}{2012} & \multicolumn{2}{|c|}{2013} & & \\
\hline & Number & $\begin{array}{c}\text { Canopy } \\
\text { Cover }\end{array}$ & Number & $\begin{array}{l}\text { Canopy } \\
\text { Cover }\end{array}$ & Number & $\begin{array}{l}\text { Canopy } \\
\text { Cover } \\
\end{array}$ \\
\hline Graminoids & 11 & 20.1 & 13 & 15.6 & 16 & 18 \\
\hline Forbs & 18 & 29.2 & 20 & 37.4 & 25 & 35.2 \\
\hline Shrubs & 2 & 0.2 & 2 & 1.4 & 2 & 0.7 \\
\hline Trees & 2 & 7.2 & 3 & 14.1 & 4 & 15.2 \\
\hline
\end{tabular}

The graminoid species with the greatest canopy cover was noxious Phalaris arundinacea in 2012 and planted Bromus carinatus (mountain brome) in 2013. Phalaris arundinacea, with its rhizome root system that aggressively outcompetes native species, also dominated in canopy cover in 2013 when including the additional quadrats (USDA NRCS 2002). The species with the greatest frequency was Bromus carinatus, found in approximately 50 percent of the quadrats across all sampling groups. The other two planted grass species had very low canopy covers. Deschampsia elongata had just 2.7 percent cover in 2012, and less than 1 percent in 2013. Lolium multiflorum (annual ryegrass) was not found in 2012 and had less than 0.1 percent of the cover in 2013.

Most of the other graminoids found on site were native wetland species occurring only on the south side of the river. These included Juncus ensifolius (daggerleaf rush), Eleocharis fallax (creeping spikerush), Sparganium emersum (European bur-reed), Typha latifolia (cattail), Juncus articulates (jointed rush), Juncus acuminatus (tapertip rush), Schoenoplectus sp. (soft or hard-stem bulrush), Eleocharis acicularis (needle spikerush), and Scirpus microcarpus (smallfruit bulrush). 
Two other volunteer perennial grass species were found on site. Poa pratensis (Kentucky bluegrass) is an introduced, sometimes weedy, species that is often found in mountainous, riparian habitats areas of the western United States (USDA NRCS 2004). Elymus glaucus (blue wildrye) is a native grass that grows well in disturbed areas and provides excellent wildlife habitat, therefore it is often used in stream bank restorations (USDA NRCS 2005).

Forbs as a group had the highest canopy cover on the site across all sampling groups (Table 8). The number of forbs as well as the canopy cover increased from 2012 to 2013. The average number of forbs in each quadrat was 2.6 in 2012 and 3.2 in 2013 , and the maximum found in a quadrat was 8 . Five new forb species were found in the quadrats added in 2013. The forb species Lotus purshianus had the greatest canopy cover in 2012 and 2013. Lotus purshianus is a native annual that often occurs on disturbed habitats in a variety of vegetation communities (Calflora 2014). It had the highest canopy cover of any of the species on the site in both years, spreading over 13 percent of the quadrats in 2012 and 14 percent in 2013. It also had the highest frequency in 2012 as it was found in 63 percent of the quadrats sampled. The forb species with the next highest canopy covers, at just 4 percent, were Lupinus rivularis and Epilobium brachycarpum. Lupinus rivularis is a native perennial that grows rapidly, adds nitrogen to the soil, and facilitates growth of grasses and other forbs (USDA NRCS 2012). The native Epilobium brachycarpum had the highest frequency in 2013 and was found in 59 percent of the quadrats.

Other forbs on site with very low canopy covers were a mix of native and introduced species. The five noxious forbs were Hypochaeris radicata - found in half of 
the 45 quadrats, Hypericum perforatum (St. John's wort), Chrysanthemum leucanthemum (oxeye daisy), Senecio vulgaris (common groundsel), and Cirsium arvense; all had canopy covers of less than 1 percent.

Only two shrubs were found, and shrubs as a group had by far the lowest canopy cover on the site (Table 8). The two shrubs were planted Salix lucida, found in 2 quadrats, and the volunteer Rubus parviflorus (thimbleberry), which was found in just one quadrat. The canopy cover of each of these species was less than 1 percent.

Just four species of native trees were found on site; all four were planted and subsist with varying success across the site (Table 8). Alnus rubra had the second highest canopy cover on the site. Its canopy cover in the original quadrats was 6 percent in 2012 and jumped to 12 percent in 2013; the canopy cover with the additional quadrats was 13 percent. The other trees found were Pseudotsuga menziesii, Acer macrophyllum, and Thuja plicata. All three of these had canopy covers less than 3 percent. The amount of bare ground increased very slightly from 2012 to $2013,36.8$ to 38.6 percent, in the original quadrats. With the additional quadrats in 2013 bare ground was at 45 percent. The number of native species was approximately 1.5 times more than introduced species in the original quadrats (Table 9). With the additional quadrats in 2013, the number of native species was twice as high as introduced species, and the mean canopy cover of native species was over four times higher and significantly different than that of introduced species (Table 10). Both the number and the canopy cover of native species increased in the original quadrats from 2012 to 2013 . The number of weeds also increased by two species, but canopy cover of those species increased only very slightly. The number of noxious species decreased, but the canopy cover increased slightly. 
Phalaris arundinacea, which was treated by the USFS, had nearly half the canopy cover in 2013, however it was found in more quadrats. Cirsium arvense, also treated, was found in only one quadrat in 2012 and none in 2013. Three of the other noxious species that were not treated had higher canopy cover and frequency in 2013, while one stayed the same and one decreased.

Table 9. Distribution of native status of species found at the site.

\begin{tabular}{|l|c|c|c|c|c|c|}
\cline { 2 - 7 } \multicolumn{1}{c|}{} & \multicolumn{4}{c|}{ Original quadrats } & \multirow{2}{*}{$\begin{array}{c}2013 \text { with additional } \\
\text { quadrats }\end{array}$} \\
\cline { 2 - 7 } \multicolumn{1}{c|}{} & \multicolumn{2}{|c|}{2012} & \multicolumn{2}{c|}{2013} & Number & $\begin{array}{c}\text { Canopy } \\
\text { Cover }\end{array}$ \\
\hline Native & 20 & 46.1 & 24 & 56.7 & 31 & 55.8 \\
\hline Weed & 7 & 4 & 9 & 4.4 & 11 & 3.4 \\
\hline Noxious & 6 & 6.6 & 5 & 7.3 & 5 & 9.8 \\
\hline
\end{tabular}

Table 10. Results of paired t-tests on 44 quadrats sampled in 2013

\begin{tabular}{|l|c|c|}
\cline { 3 - 3 } \multicolumn{1}{c|}{} & t-statistic & Significance \\
\hline Native & 6.179 & 0.00 \\
\cline { 1 - 1 } Non-Native & \multirow{2}{*}{6.475} & 0.00 \\
\cline { 1 - 1 } Volunteer & \\
\cline { 1 - 1 } Planted & \\
\hline
\end{tabular}

The number of volunteer species was 4 to 5 times higher than the number of planted species found at the site (Table 11). With the additional quadrats in 2013, the mean canopy cover of volunteer species was nearly three times higher and significantly different than that of planted species (Table 11). The number and canopy cover of 
volunteer species and planted species increased from 2012 to 2013 . Volunteer species increased by slightly more than planted species.

Table 11. Distribution of volunteer and planted species at the site.

\begin{tabular}{|l|c|c|c|c|c|c|}
\cline { 2 - 7 } \multicolumn{1}{c|}{} & \multicolumn{4}{c|}{ Original quadrats } & \multicolumn{2}{c|}{$\begin{array}{c}2013 \text { with additional } \\
\text { quadrats }\end{array}$} \\
\cline { 2 - 7 } \multicolumn{1}{c|}{2012} & \multicolumn{2}{c|}{2013} & Canopy \\
\cline { 2 - 7 } & Number & $\begin{array}{c}\text { Cover } \\
\text { Number }\end{array}$ & $\begin{array}{c}\text { Canopy } \\
\text { Cover }\end{array}$ & Number & $\begin{array}{c}\text { Canopy } \\
\text { Cover }\end{array}$ \\
\hline Volunteer & 28 & 43.18 & 31 & 49.7 & 39 & 50.7 \\
\hline Planted & 5 & 13.52 & 7 & 18.8 & 8 & 18.4 \\
\hline
\end{tabular}

\section{Correlations with Environmental Variables}

The maximum rate of infiltration at the site was deemed an outlier related to sampling and was therefore removed for statistical analysis. The mean infiltration rate of $55.2 \mathrm{~cm} / \mathrm{hr}$ reflects a very rapid infiltration rate that is typical of sandy soils (Lowery et al. 1996). Chlorophyll was measured at 35 of the 45 quadrats, with ten quadrats having no Alnus rubra within 5 meters. The atLEAF+ units were converted to $\mathrm{mg} / \mathrm{cm}^{2}$. The range of values that the atLEAF+ meter picks up is 0 to 99 atLEAF+ units, or 0.003 to $0.13 \mathrm{mg} / \mathrm{cm}^{2}$ (atLEAF 2013); the range of values at the site was $0.03-0.06 \mathrm{mg} / \mathrm{cm}^{2}$ with a mean of $0.05 \mathrm{mg} / \mathrm{cm}^{2}$ (Table 12). The elevation varied by only 4 meters across the site; distance of the quadrats from the stream varied widely, but the average is approximately halfway between the river and native forest. 
Table 12. Environmental variables measured at each quadrat.

\begin{tabular}{|l|c|c|c|c|}
\hline \multicolumn{1}{|c|}{ Variable } & Minimum & Maximum & Mean & Standard Deviation \\
\hline Distance from Stream $(\mathrm{m})$ & 8.9 & 72.5 & 33.1 & 17.6 \\
\hline Elevation $(\mathrm{m})$ & 325.2 & 329.8 & 328.3 & 1.2 \\
\hline Infiltration $(\mathrm{cm} / \mathrm{hr})^{*}$ & 2.9 & 205.6 & 55.2 & 56.1 \\
\hline Chlorophyll $\left(\mathrm{mg} / \mathrm{cm}^{2}\right)$ & 0.03 & 0.06 & 0.05 & $<0.003^{* *}$ \\
\hline
\end{tabular}

* Values reflect statistics after removal of outlier

** Standard deviation less than lowest detection limit of chlorophyll meter

Three variables showed a significant correlation with infiltration rates (Table 13). Species richness and native canopy cover were both inversely correlated, meaning an increase in infiltration was related to a decrease in these variables. Bare ground was strongly positively correlated with infiltration, suggesting that higher infiltration rates, which are indicative of sandy soils, were related to more bare ground. Distance from stream was also significantly correlated with three variables. A positive correlation existed between distance and non-native canopy cover, graminoid cover, and volunteer species cover. Elevation was positively correlated with graminoid cover, volunteer species cover, and Simpson's Index. Chlorophyll was positively correlated with infiltration, but not with vegetation groups. 
Table 13. Significant correlations of classification groups with environmental variables.

\begin{tabular}{|c|l|c|c|}
\hline Variable & Classification Group & Pearson Correlation & Significance \\
\hline \multirow{3}{*}{ Infiltration } & Species richness & -0.40 & 0.02 \\
\cline { 2 - 4 } & Native & -0.42 & 0.01 \\
\cline { 2 - 4 } & Bare Ground Cover & 0.61 & $<0.001$ \\
\hline \multirow{3}{*}{ Distance } & Non-Native & 0.33 & 0.03 \\
\cline { 2 - 4 } & Graminoid & 0.46 & 0.001 \\
\cline { 2 - 4 } & Volunteer & 0.37 & 0.01 \\
\hline \multirow{3}{*}{ Elevation } & Simpson's Index & 0.35 & 0.02 \\
\cline { 2 - 4 } & Graminoid & 0.37 & 0.01 \\
\cline { 2 - 4 } & Volunteer & 0.29 & 0.05 \\
\hline
\end{tabular}

The Pearson's correlation matrix also showed other correlations between canopy covers. For example, total canopy cover, native cover, and forb cover were all negatively correlated with bare ground. Also, volunteer species were highly positively correlated with graminoid and forb species. 


\section{DISCUSSION}

Vegetation Recovery after Dam Removal

During this study, the site was in its third and fourth years of succession following a major disturbance, the dam removal and dewatering of the landscape. This site appears to still be in the herbaceous stage of succession, dominated by both native and non-native forbs and grasses. A mere two shrubs and four trees were found on the site in the 48 quadrats in 2013, and they covered just 16 percent of the site as opposed to 41 species of forbs and graminoids that covered over 50 percent of the site. Of the eight new species found in the additional 24 quadrats sampled in 2013, seven were forbs or graminoids and just one was a tree. Shrub canopy cover was very low in both years; hence, it does not appear that they will be dominating in the near future. However, tree cover doubled in the second year of sampling, demonstrating that there are enough resources for trees to thrive here. The high incidence of bare ground demonstrates that much of the site is still lacking vegetation and leaf litter.

The high incidence of forbs and grasses is not surprising due to the unique disturbance at this site. After a disturbance, such as fire or logging, some shrubs and trees may still be left on the site and can spread their seeds creating a hospitable habitat for other species. Though there may not be residual species with mud and debris flows, the pulse of sediment that arrives at the site could bring a variety of seeds from species upstream as well as soils that contain organic matter. In the case of a dam removal, the reservoir is simply drained and sediments that have been inundated for many years are exposed. There may be little to no seed bank, as well as soils low in organic matter, on a 
site that is bare, open, and exposed. In such a setting, this study confirmed that ruderal species are the first to colonize, and bare ground is abundant. Forbs and grasses may continue to dominate for many years at this site as there is no shade to discourage them and little to no organic matter to set the stage for woody species. If trees continue to increase their canopy cover at this site, they may create shade and leaf litter that could help build the soil and shade out the current species, possibly drastically changing the habitat.

The canopy cover and frequency of a majority of species at the site increased in the second year of sampling. Only three species found in the first year of sampling were not found in the second year, suggesting that most of the species that established soon after disturbance are persisting in this environment. However, the average Simpson's Index stayed the same across the years, suggesting that species diversity overall is not actually increasing; there is an increase in species richness, but not in evenness as a few species continue to dominate. The rank abundance curve strengthened this notion as its steep curve suggests that the site was dominated by a small number of species, including Alnus rubra and Lotus purshianus, and that the dominance of these plants only increased from 2012 to 2013.

Similar to the study by Rohdy (2013) at a dam removal site in Lassen National Park, most of the species found on this site were native. Native species had approximately five times more cover on the site than introduced species, and they were the only plant classification group that showed a significant increase in 2013. This is in contrast to other dam removal studies such as those done by Lenhart (2000) and Orr and 
Stanley (2006) in Wisconsin, which found very high incidence, and sometimes a monoculture, of invasive species, such Phalaris arundinacea. The high cover of natives at this site may be due to the fact that land use in the drainage area above the site is federal owned forest land; hence, with relatively few roads and low human impact, weeds are not spread as readily and native species can thrive. In contrast, the land use at the Wisconsin dam removal sites was private timber and agricultural land.

Two native species had dramatically more canopy cover than other species. Lotus purshianus is an annual species that occurs across the western U.S. and is known to colonize bare, open substrates (Figure 7). It is generally considered desirable for habitat restoration, and it is an important food source for native wildlife (DiTomaso, Healy, and Rejmanek 2007). Alnus rubra is also widespread across the western U.S (Figure 7). It germinates profusely and grows very quickly, as much as one meter per year, but lives to only 100 years. It is well-adapted to disturbed riparian sites where it fixes atmospheric nitrogen, providing a rich setting for other species (DiTomaso, Healy, and Rejmanek 2007, Pabst and Spies 2001). 

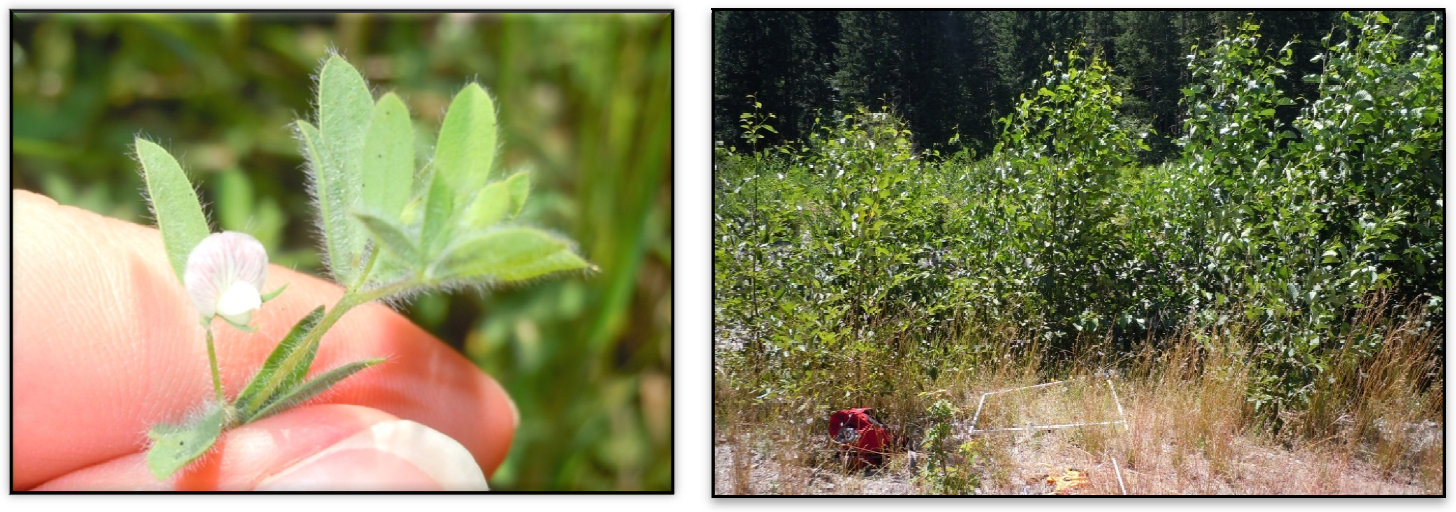

Figure 7. Lotus purshianus (left) and Alnus rubra (right) from the study site.

While native species cover is high, the species found here do not resemble the immediate surrounding forests at the site (Figure 8). While this site is dominated by Alnus rubra at the canopy level, the forest nearby is dominated by Acer macrophyllum, Thuja plicata, and Pseudotsuga menziesii. The shrub level is nearly nonexistent at this site and groundcover is mostly grasses and forbs, whereas the forest has ample native species at the shrub and ground level. Therefore it may be assumed that seeds may not be coming from the forest immediately surrounding the site, but rather being spread to this site via water, wind, or animals. For instance, the seeds may be traveling via water from other areas upstream, such as floodplains, or with wind from rural lands nearby. Vehicles on the roads immediately surrounding the site may also introduce seeds from further away. 


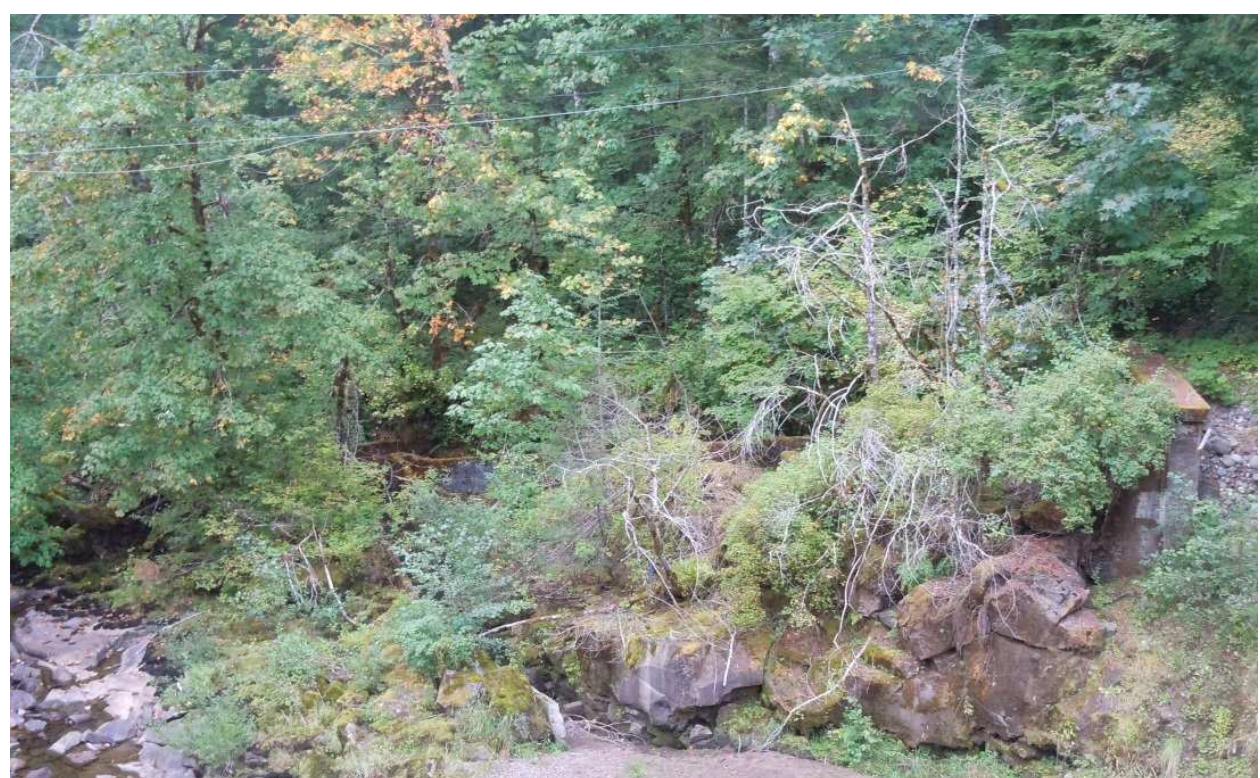

Figure 8. Native forest vegetation just downstream of the dam removal.

The aggressive treatment of invasive species, which was not done at the Wisconsin sites where invasive species thrived, likely allowed native species to occupy and dominate the site. Two of the invasive species that the USFS has treated, Phalaris arundinacea and Cirsium arvense, were found on the site. Nearly four acres of the site was wetlands dominated by Phalaris arundinacea before dam removal, but this species had less than three percent cover on the site in 2013. It appears that treatment, which began immediately after dam removal and is still occurring, has been successful in preventing the spread of some of the noxious species, while others that were not treated had more, but still relatively low, canopy cover in the second year. Other factors that may have contributed to the low cover of noxious species include a lack of seed source upstream in the native forests, and a change in habitat as the reservoir drainage made 
areas that were previously wetland, the preferred habitat for Phalaris arundinacea, into dry upland areas.

Other invasive species were found at this site that are not being treated. These could have come from further away with wind or water dispersal, or they could have been surrounding the site prior to dam removal but not deemed a priority by the USFS. There were also weedy species found on site, which were not considered invasive. Introduced species can be expected at a disturbed site such as this. They are generally found at early seral sites for two to five years after a disturbance, but they should be replaced by native shrubs and trees as succession continues. As the shade from Alnus rubra increases, it can be expected that many of these species may decrease or become eliminated as they require ample sun (Pabst and Spies 2001). For instance, quadrats in this study seemed to have higher cover of introduced species when they were in the open rather than under the shade of Alnus rubra (Figure 9).

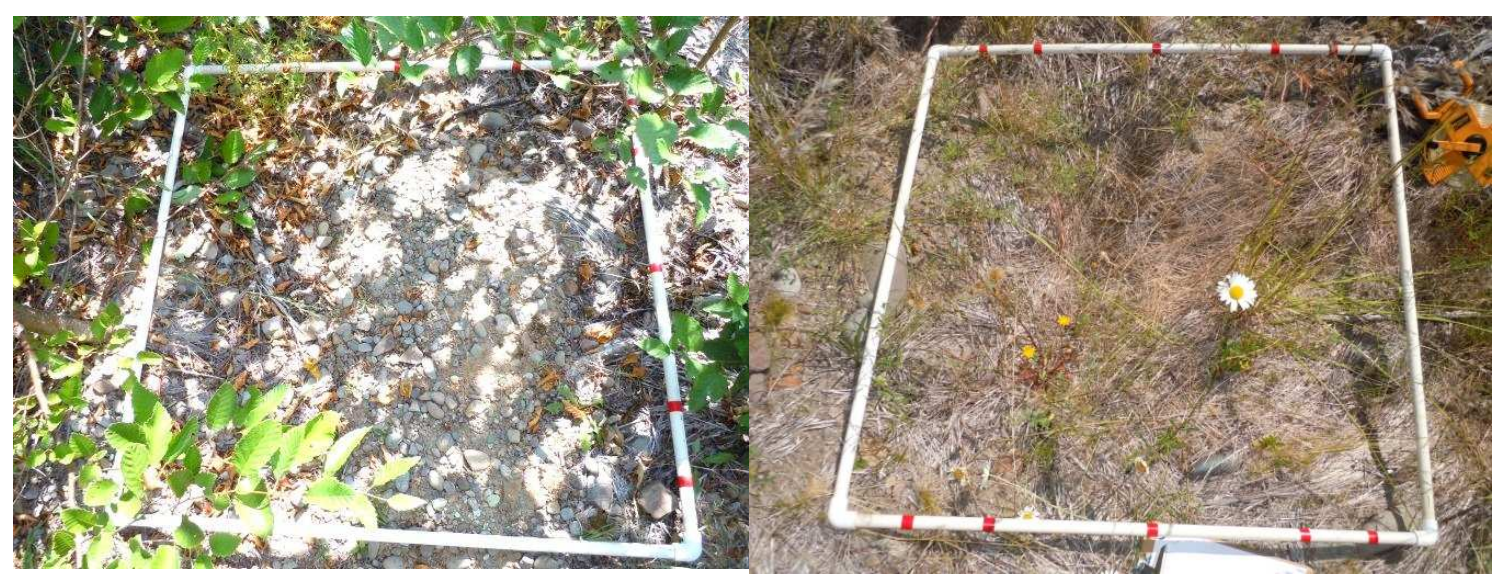

Figure 9. Quadrat shaded by Alnus rubra (left), and quadrat with ample sun. 
The plants on this site are markedly different from another large, nearby fluvial disturbance. Following the eruption of Mount St. Helens a mudflow inundated the Muddy River creating large areas of wet, bare ground. In that location researchers found a mix of volunteer trees, shrubs, and herbs just one year after disturbance (Halpern and Harmon 1983). However, the Hemlock dam removal site may be proceeding similar to a debris flow studied by Pabst and Spies (2001) where the herbaceous stage lasted 7 years on bare sediment. The researchers in that study thought forbs and grasses may be dominating because of a lack of shade resulting from a low amount of woody species.

This site may also proceed similar to old field sites that are left to re-vegetate after farmlands have been abandoned. The only study on old field succession in the Pacific Northwest was completed in the Queets River Valley of Olympic National Park. Riege and Del Moral (2004) found that old fields were dominated by non-native grasses and herbaceous species 60 years after desertion. Also, though these fields were completely surrounded by temperate rain forest, the dominant natives in the rain forest were rare in the old field due to competition with non-native species. Other old field studies have been done on the East Coast, where non-native grasses and forbs invade the site initially, trees and shrubs establish after 15-45 years, and hardwoods dominate by 100 years after abandonment (Copenheaver 2008). Researchers have found that native species increase significantly while non-native species cover stays steady or decreases over time. The plant classifications also change from short-lived herbs to long-lived woody species due to canopy closure that shades out non-native herbaceous species (Meiners, Pickett, and Cadenasso 2002). 
At Hemlock, where native species cover is increasing significantly and non-native species are present but not increasing significantly, succession seems to be proceeding similar to the old-field sites on the East Coast. Since herbaceous species are dominating here also, we can predict that a decade or more may pass before woody species have a presence at the site and can begin to shade out these species, although the woody species may not resemble those in the surrounding forest. If it continues on a similar path of succession, it may take up to a century before hardwoods dominate. However, the main difference between Hemlock and the old-field sites is that Hemlock had managed planting and invasive species removal, which has already led to increased native and woody species cover at the site. Because of this, there is much uncertainty about how succession will proceed at this unique site.

\section{Success of planting}

A main priority for the dam removal was restoring native vegetation; hence the USFS took an active role in re-vegetation by planting grasses, shrubs, and trees. This is in contrast to the management of the Wisconsin and Elwha dams, but similar to the management of the Condit Dam removal site. Nearly all of the Wisconsin sites were left to natural re-vegetation. At Elwha, they are planning to restrict re-vegetation to areas greater than 50 meters from the native forest because they believe seeds will travel from the forest to these portions of the site and colonize. Most of the Hemlock site is within 50 meters of the forest; however, the USFS decided to re-vegetate rather than let the vegetation return naturally at this site because they presumed that invasive species would otherwise dominate the site. At Condit and Hemlock there have been no forbs planted, 
but there are forbs being planted at the Elwha dam removals. The USFS decided not to plant groundcover species at Hemlock because they thought these species would not survive without humus in the soil and some shade (Ruchty 2013).

This study showed that canopy cover of planted species was less than half that of volunteer species. Additionally, there was no straightforward way to identify individual species that were planted from those that may have volunteered, so it is possible that some of the plants, especially Alnus rubra, may have established on their own, which would increase the success of volunteers. Planted species had a notable presence, occupying nearly 20 percent cover by 2013 ; however, nearly three fourths of this cover was due to Alnus rubra. The USFS did, in fact, plant more Alnus rubra than any other species, and they placed them evenly across the site. Though this species is sometimes a controversial restoration tool because of its short life and tendency to crowd out other native species, USFS planted Alnus rubra for its ability to grow quickly, build soil with nitrogen and humus from leaf litter, and shade out invasive species (Ruchty 2013). Some of the species planted here were not found in this study. Of the four planted shrubs only Salix lucida was found in the quadrats, and none of the other three planted shrubs could be found on the site during exhaustive surveys of the study area. All grasses and trees were either found in the quadrats or spotted on the site. However, other than Alnus rubra no planted species had higher than four percent canopy cover in this study.

A variety of factors have contributed to the low cover of most of the planted species. It appears that elk have grazed on all of the planted trees except for Alnus rubra, as well as some if not all of the shrubs. As a result, the trees have become low and 
shrubby with stunted growth (Figure 10). Excavators and trucks driving across the site during dam removal activities left some areas compacted, and species have not done as well on these areas. Some plants were planted with bare roots, and it took two years before they began to grow. Other plants were planted in long pots because the USFS thought they would survive better in the hope that the roots would get access to the water table; however, they had trouble getting the pots to the right depth, because the sandy soil kept collapsing in on the holes they dug. Therefore, those plants may not have survived (Ruchty 2013). Also, mulching, which could have increased moisture in the soil and possibly increased survival was not used during the planting process. This site also lacked facilitation, which can also play a major factor in how seedlings establish in Pacific Northwest disturbed habitats as demonstrated by Karps (2006). Her study found that seedlings tend to grow especially well on decomposed woody litter that holds moisture, and also under shrubs, or adjacent to or under logs, and establish much less in open areas devoid of these facilitators. 


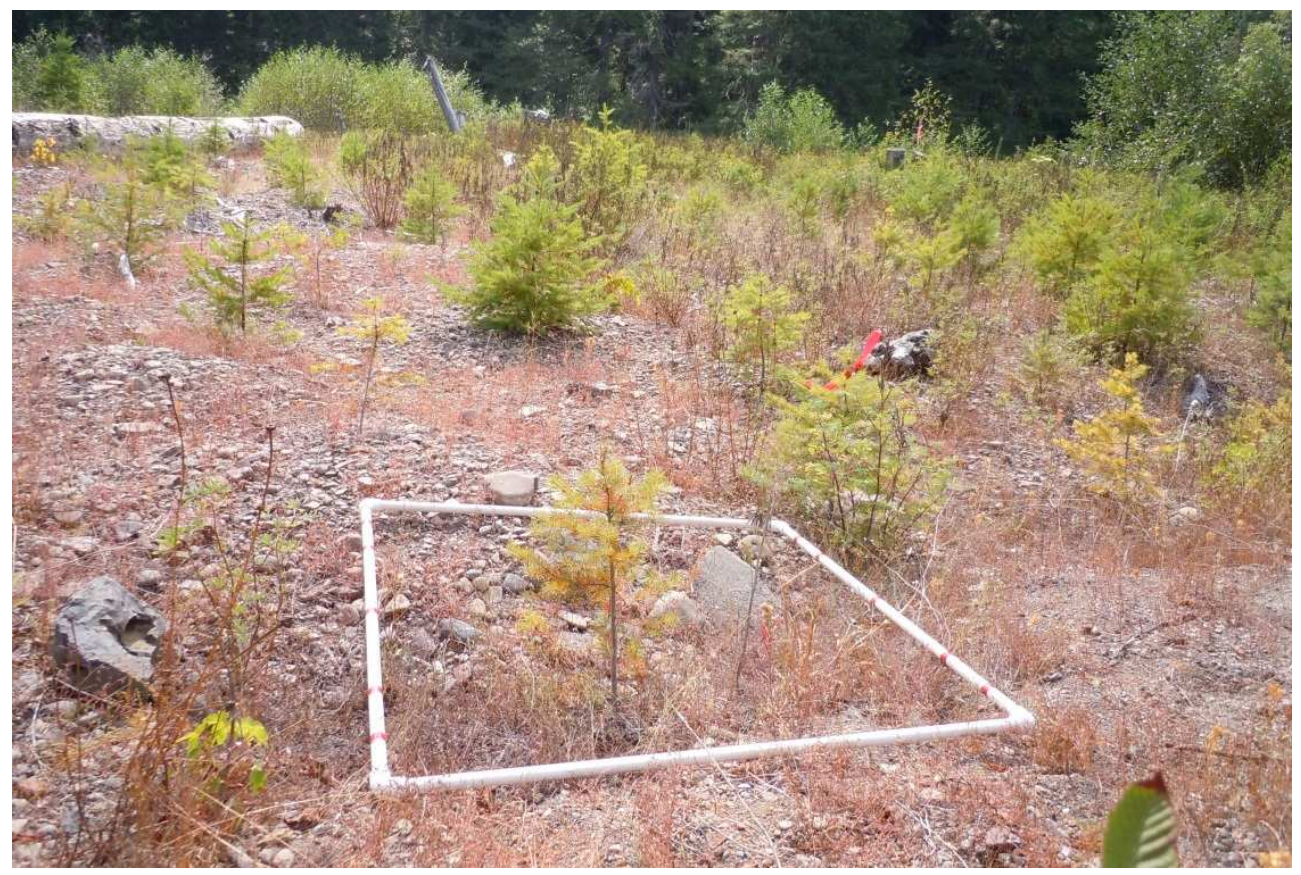

Figure 10. Stunted Pseudotsuga menziesii found on the site.

A method that the USFS thought was profoundly important to the success of their planting was irrigation. They irrigated for three seasons after dam removal with irrigation line leftover from operations at the nursery that once existed adjacent to the site. Water was pumped out of the creek per a permit from the State of Washington. Many restoration sites would not have access, organization, or funding to do this. It is unclear whether this practice had a significant impact, particularly in bare ground areas where the sandy soils could not store the irrigated water.

\section{Influence of environmental variables on vegetation}

Several environmental variables may have an influence on vegetation recovery at this site. Infiltration, distance from stream, and elevation were all correlated with one or 
more plant classification groups. The negative correlation of infiltration with species richness and native canopy cover, as well as the positive correlation with bare ground, suggests that the sandy sediments at this site may be preventing the growth of species. Water may be successfully soaking into the soil, but then leaving the area of the roots before plants are able to absorb it. However, this study also found that chlorophyll rates were positively correlated with infiltration. This may suggest that Alnus rubra species are thriving on the sandy soils, as it is well adapted to highly disturbed environments such as sandy floodplains.

The positive correlation of distance from stream with non-native, graminoid, and volunteer species suggest that these groups are thriving nearer to the edge of the reservoir, where the native forest begins. This may suggest that these populations are originating from the former reservoir edge rather than being spread by seed carried by the stream. Non-native species may be more prevalent near the edge of the reservoir because there were populations of invasive species around the reservoir prior to dam removal as is the case in the Wisconsin sites. Also, many graminoids were found in wetlands, which are close to the edge of the former reservoir. Volunteer species are included because they are highly correlated with graminoid species. These results are slightly different from the study by Halpern and Harmon (1983) after a mudflow, which found that trees, shrubs, and forbs decreased with distance from the forest.

There may be similar explanations for the positive correlation of elevation with graminoids and volunteer species because elevation is also strongly correlated with distance from stream in that elevation increases away from the stream channel. 
Simpson's Index was also positively correlated with elevation, which suggests that areas at higher elevation had more richness and/or evenness. However, elevation and distance from stream were not correlated with overall canopy cover or species richness so it may be that quadrats at a higher elevation simply have species that have about the same evenness in terms of canopy cover. This is different from the study by Del Moral, Sandler, and Muerdter (2009) that found richness and percent cover decreased with elevation, although the study area was much larger with more variation in elevation. The USFS thought that elevation would be profoundly important on the site because areas with higher elevation wouldn't have access to the water table, and therefore the plants would not survive (Ruchty 2013). However, that result was not found in this study.

The Hemlock site may be impacted by other USFS actions in the near future. In the summer of 2013, two of the quadrats that I established in August, B4Q1 and B4Q1R, were destroyed in September as an area was cleared in preparation for a new side channel. This will open up a newly disturbed, bare area where successional processes will again start over. Also, because the Pseudotsuga menziesii trees were planted so close together thinning might be necessary in the future, which will present a new disturbance. USFS staff are currently monitoring vegetation at the site; however, that funding will end after this year stopping regular monitoring. More groundcover species may be planted in the future, but this will depend on securing a new source of funding (Ruchty 2013). 


\section{CONCLUSION}

Dam removal has many ecological benefits as it restores the river to a freeflowing condition and generally improves aquatic habitat. However, though one goal of removal is often to restore riparian habitats in order to increase shade and large woody debris, dam removal leaves an area with bare sediments that must undergo primary succession. This provides an advantageous setting for invasive species and other ruderal species that prefer disturbed habitats. Because of this, agencies often plant native species to encourage a diverse native plant community that resembles the form and function of forests nearby.

The site for this study, former Hemlock Dam, was one such project where active re-vegetation was done because there was a large reservoir area that was drained and susceptible to invasion by exotic species. Vegetation recovery of both volunteer and planted species was explored by examining canopy cover in the third and fourth year following dam removal. The results of this study show that the former reservoir area is now dominated by mostly native species, with a native planted tree and a native ruderal forb having far more cover than other species on the site. Though most of the species were native, they are mostly grasses and forbs characteristic of an early succession and therefore do not resemble the surrounding vegetation which is characteristic of a Pacific Northwest Tsuga heterophylla vegetation zone. Invasive species were present at the site but had low canopy covers. Some planted species were found in this study but besides Alnus rubra they had low canopy cover, others were not found or seen on site suggesting that they had low survival rates. The success of some plant groups, particularly 
graminoids, was found to be correlated with environmental variables such as distance from stream, elevation, and infiltration.

This study adds to the small but increasing literature regarding vegetation growth following dam removal. The results will give Pacific Northwest resource managers a better idea of the kinds of plant species that are best able to persist after dam removals. They will be better informed about the success of active re-vegetation and invasive species control so that they can determine whether these techniques are necessary at their site. It also provides data representative of how vegetation may respond to different environmental variables.

By examining two years of vegetation growth, this study was able to explore changes that take place over time at a highly disturbed site. However, this study was also limited by being only a two-year snapshot. To obtain a more complete documentation of successional changes over an extended period of time, this study should be repeated in five to ten years. Having carefully documented each plant species, and collecting GPS points and pictures, future researchers could find each quadrat and collect additional data in the same manner that repeat studies at the Muddy River near Mt. St. Helens have been done over the past several decades. This could be beneficial whether the 24 original quadrats or the full 48 quadrats were used as the data revealed similar trends, which suggests that the sample size may have been adequate enough in the first year. Researchers should also pursue soil studies at this site by gaining funding from outside sources in order to hire a USFS archeologist. Soil properties were highly influential on vegetation dynamics following dam removal at the Lassen site, and likely are also 
important here. Similar studies should be done at Condit dam as that site is undergoing active re-vegetation that is similar to what was tried at Hemlock, and as this study demonstrates, much more work needs to be done on evaluating the success of different planting techniques after dam removal to determine the species and scale of effort that works best in Pacific Northwest habitats. 


\section{REFERENCES}

atLEAF. 2013. atLEAF+ to SPAD units. http://www.atleaf.com/SPAD.aspx (last accessed 31 March 2014).

Bendix, J. 1994. Scale, Direction, and Pattern in Riparian Vegetation-Environment Relationships. Annals of the Association of American Geographers 84(4): 652-665.

Auble, G. T. 2007. Early Vegetation Development on an Exposed Reservoir: Implications for Dam Removal. Environmental Management 39(6): 806-818.

Babbitt, B. 2002. What Goes Up, May Come Down. BioScience 52(8): 656-658.

Bednarek, A. T. 2001. Undamming Rivers: A Review of the Ecological Impacts of Dam Removal. Environmental Management 27(6): 803-814.

Born, S. M., K. D. Genskow, T. L. Filbert, N. Hernandez-Mora, M. L. Keefer, and K. A. White. 1998. Socioeconomic and Institutional Dimensions of Dam Removals: The Wisconsin Experience. Environmental Management 22(3): 359-370.

Brouwer, C., K. Prins, M. Kay, and M. Heibloem. 1988. Irrigation Water Management: Irrigation Methods. Food and Agriculture Organization of the United Nations. Rome, Italy. http://www.fao.org/docrep/s8684e/s8684e00.HTM (last accessed 31 March 2014).

Bureau of Land Management National Applied Resource Sciences Center. 1999. Sampling Vegetation Attributes, Interagency Technical Reference 1734-4. Denver, CO. http://www.blm.gov/nstc/library/pdf/samplveg.pdf (last accessed 31 March 2014).

Calflora. 2014. Lotus purshianus. Berkeley, CA. http://www.calflora.org/cgibin/species_query.cgi?where-taxon=Lotus+purshianus (last accessed 31 March2014).

Chenoweth, J., S. A. Acker, and M. L. McHenry. 2011. Revegetation and Restoration Plan for Lake Mills and Lake Aldwell. Olympic National Park and the Lower Elwha Klallam Tribe. Port Angeles, WA. http://www.nps.gov/olym/naturescience/elwharestoration-docs.htm (last accessed 31 March 2014).

Coffin, B. 2011. Hemlock Dam Removal Final Report. U. S. Forest Service Mt. Adams Ranger District. Trout Lake, WA.

Cook, K. L., W. W. Wallender, C. S. Bledsoe, G. Pasternack, and S. K. Upadhyaya. 2011. Effects of Native Plant Species, Mycorrhizal Inoculum, and Mulch on Restoration of Reservoir Sediment Following Dam Removal, Elwha River, Olympic Peninsula, Washington. Restoration Ecology 19(2): 251-260. 
Copenheaver, C. A. 2008. Old-Field Succession in Western New York: The Progression of Forbs and Woody Species from Abandonment to Mature Forest. Rhodora 110(942): 157-170.

del Moral, R., J. E. Sandtler, C. P. Muerdter. 2009. Spatial Factors Affecting Primary Succession on the Muddy River Lahar, Mount St. Helens, Washington. Plant Ecology 202(1): 177-190.

DiTomaso, J. M., E. A. Healy, and M. Rejmanek. 2007. Weeds of California and Other Western States. Oakland, CA: University of California Division of Agriculture and Natural Resources.

Doyle, M. W., E. H. Stanley, C. H. Orr, A. R. Selle, S. A. Sethi, and J. M. Harbor. 2005. Stream Ecosystem Response to Small Dam Removal: Lessons from the Heartland. Geomorphology 71(1-2): 227-244.

Eash, N. S., M. C. Bratz, and M. I. Harpstead. 2008. Soil Science Simplified. Ames, IA: Blackwell Publishing.

Franklin, J. F. and C. T. Dyrness. 1973. Natural Vegetation of Oregon and Washington. Portland, OR: Pacific Northwest Forest and Range Experiment Station, Forest Service, U.S. Dept. of Agriculture.

Halpern, C. B., and M. E. Harmon. 1983. Early Plant Succession on the Muddy River Mudflow, Mount St. Helens, Washington. American Midland Naturalist 110 (1): 97-106.

Hoffert-Hay, D. 2008. Small Dam Removal in Oregon. Salem, OR: Oregon Watershed Enhancement Board.

Howard, Dave. 2004. Wind River Watershed Temperature Total Maximum Daily Load: Detailed Implementation Plan. Olympia, WA: Washington State Department of Ecology.

Jumpponen, A., H. Vare, K. G. Mattso, R. Ohtonen, and J. M. Trappe. 1999.

Characterization of 'Safe Sites' for Pioneers in Primary Succession on Recently

Deglaciated Terrain. Journal of Ecology 87(1): 98-105.

Lafrenz , M. D., R. A. Bean, and D. Uthman. 2013. Soil Ripening Following Dam Removal. Physical Geography 34(2): 124-135.

Lenhart, C. F. 2000. The Vegetation and Hydrology of Impoundments after Dam Removal in Southern Wisconsin. MS Thesis, University of Wisconsin, Madison.

Lower Columbia Fish Recovery Board (LCFRB). 2004. Lower Columbia Salmon Recovery and Fish \& Wildlife Subbasin Plan. Longview, WA. 
Lowery B., W. J. Hickey, M. A. Arshad, and R. Lal. 1996. Soil Water Parameters and Soil Quality. In Methods for Assessing Soil Quality, ed. J. W. Doran and A. J. Jones. Madison, WI: Soil Science Society of America.

Major, J. J., J. E. O’Connor, C. J. Podolak, M. K. Keith, G. E. Grant, K. R. Spicer, S. Pittman, H. M. Bragg, J. R. Wallick, D. Q. Tanner, A. Rhode, and P. R. Wilcock. 2012. Geomorphic Response of the Sandy River, Oregon, to Removal of Marmot Dam. Reston, VA: U.S. Geological Survey. http://pubs.usgs.gov/pp/1792/ (last accessed 31 March 2014).

Meiners, S. J., Pickett, S. T., and Cadenasso, M. L. 2002. Exotic Plant Invasions Over 40 Years of Old Field Successions: Community Patterns and Associations. Ecography 25(2): 215-223.

Michel, J. T., J. M. Helfield, and D. U. Hooper. 2011. Seed Rain and Revegetation of Exposed Substrates Following Dam Removal on the Elwha River. Northwest Science 85(1):15-29.

Naiman, R. J., and H. Décamps. 1997. The Ecology of Interfaces: Riparian Zones. Annual Review of Ecology and Systematics 28: 621-658.

National Park Service. 2013. Dam Removal Blog. http://www.nps.gov/olym/naturescience/damremovalblog.htm (last accessed 31 March 2014).

Nilsson, C., and K. Berggren. 2000. Alterations of Riparian Ecosystems Caused by River Regulation. BioScience 50(9): 783-792.

Orr, C. H, and E. H. Stanley. 2006. Vegetation Development and Restoration Potential of Drained Reservoirs Following Dam Removal in Wisconsin. River Research and Applications 22 (3): 281-295.

Pabst, R. J., and T. A. Spies. 2001. Ten Years of Vegetation Succession on a Debris-flow Deposit in Oregon. Journal of the American Water Resources Association 37(6):16931708.

PacifiCorp. 2011. Condit Hydroelectric Project Decommissioning Revegetation and Wetlands Management Plan. Portland, OR. http://www.pacificorp.com/content/dam/pacificorp/doc/Energy_Sources/Hydro/Hydro_Li censing/Condit/20110315RevegWetlandsMgmtPlan.pdf (last accessed 31 March 2014).

Pacific Northwest Research Station. 2003. Wind River Experimental Forest. U.S. Dept. of Agriculture, Forest Service. Portland, OR. http://purl.access.gpo.gov/GPO/LPS43268 (last accessed 31 March 2014). 
Poff, N. L., and D. D. Hart. 2002. How Dams Vary and Why It Matters for the Emerging Science of Dam Removal. Bioscience 52(8): 659-668.

Pojar, J., A. MacKinnon, and P. B. Alaback. 1994. Plants of the Pacific Northwest Coast: Washington, Oregon, British Columbia \& Alaska. Redmond, WA: Lone Pine Publishing.

Randle, T. J., and B. Greimann. 2004. Sediment Impact Analysis for the Proposed Hemlock Dam Removal Project: Gifford Pinchot National Forest - Skamania County. Denver, CO: U.S. Department of the Interior, Bureau of Reclamation.

http://www.usbr.gov/pmts/sediment/projects/hemlock/download/HemlockSedimentImpac ts.pdf (last accessed 31 March 2014).

Riege, D. A.,and R. Del Moral. 2004. Differential Tree Colonization of Old Fields in a Temperate Rain Forest. The American Midland Naturalist 151(2): 251-264.

Rohdy, S. 2013. Soil Development and Vegetation Response to Removal of a Small Dam, Lassen Volcanic National Park, California. MS Thesis, Portland State University.

Rot, B., R. Naiman, and R. Bilby. 2000. Stream Channel Configuration, Landform, and Riparian Forest Structure in the Cascade Mountains, Washington. Canadian Journal of Fisheries and Aquatic Sciences 57: 699-707.

Ruchty, A. 2011. Hemlock Dam Removal and Trout Creek Restoration Project Revegetation Portion Year Two Post Implementation. Trout Lake, WA: Gifford Pinchot National Forest, Mt. Adams Ranger District.

Ruchty, A. 2013. South Zone Botanist, Gifford Pinchot National Forest, Trout Lake, WA. Personal interview, November 1.

Ryke, N. 2005. Record of decision: Fish Passage and Aquatic Habitat Restoration at Hemlock Dam. Trout Lake, WA: Gifford Pinchot National Forest, Mt. Adams Ranger District.

Shafroth, P. B., J. M. Friedman, G. T. Auble, M. L. Scott, and J. H. Braatne. 2002. Potential Responses of Riparian Vegetation to Dam Removal. BioScience 52(8): 703-712.

Stanley, E. H., and M. W. Doyle. 2003. Trading Off: The Ecological Effects of Dam Removal. Frontiers in Ecology and the Environment 1(1): 15-22.

Simpson, E.H. 1949. Measurement of Diversity. Nature 163: 688.

Taylor, R. 1990. Northwest weeds: The Ugly and Beautiful Villains of Fields, Gardens, and Roadsides. Missoula, MT: Mountain Press Publishing Company. 
U.S. Department of Agriculture Natural Resources Conservation Board (NRCS). 2002. Plant Guide Reed Canarygrass. http://plants.usda.gov/plantguide/pdf/pg_phar3.pdf (last accessed 31 March 2014).

U.S. Department of Agriculture Natural Resources Conservation Board (NRCS). 2004. Plant Guide Kentucky Bluegrass. https://plants.usda.gov/plantguide/pdf/pg_popr.pdf (last accessed 31 March 2014).

U.S. Department of Agriculture Natural Resources Conservation Board (NRCS). 2005. Plant Guide Blue Wildrye. http://plants.usda.gov/plantguide/pdf/pg_elgl.pdf (last accessed 31 March 2014).

U.S. Department of Agriculture Natural Resources Conservation Board (NRCS). 2012. Plant Guide Riverbank Lupine. http://plants.usda.gov/factsheet/pdf/fs_luri.pdf) (last accessed 31 March 2014).

U.S. Department of Agriculture Natural Resources Conservation Board (NRCS). 2014. PLANTS Database. http://plants.usda.gov/ (last accessed 12 May 2014).

U.S. Forest Service (USFS). 2005. Final Environmental Impact Statement: Fish Passage and Aquatic Habitat Restoration at Hemlock Dam. Trout Lake, WA: Mount Adams District, Gifford Pinchot National Forest.

Washington State Noxious Weed Control Board. 2013. 2013 Washington State Noxious Weed List. http://www.nwcb.wa.gov/printable.htm (last accessed 31 March 2014).

Weinmann, F., M. Boule, K. Brunner, J. Malek, and V. Yoshino. 1984. Wetland plants of the Pacific Northwest. Seattle, WA: U.S. Army Corps of Engineers.

Woodward, A., C. Torgersen, J. Chenoweth, K. Beirne, and S. Acker. 2011. Predicting Spread of Invasive Exotic Plants into De-watered Reservoirs Following Dam Removal on the Elwha River, Olympic National Park, Washington. Reston, VA: U.S. Geological Survey.

Zhu, J., N. Tremblay, and L. Yinli. 2012. Comparing SPAD and atLEAF Values for Chlorophyll Assessment in Crop Species. Canadian Journal of Soil Science 92(4): 645648. 